\title{
An in situ intercomparison exercise on passive samplers for monitoring metals, polycyclic aromatic hydrocarbons and pesticides in surface waters
}

\author{
C. Miège ${ }^{1,{ }^{*}}$, N. Mazzella ${ }^{2}$, S. Schiavone ${ }^{1}$, A. Dabrin ${ }^{1}$, C. Berho ${ }^{3}$, J-P. Ghestem ${ }^{3}$, C. Gonzalez ${ }^{4}$, \\ JL. Gonzalez ${ }^{5}$, B. Lalere ${ }^{6}$, S. Lardy-Fontan ${ }^{6}$, B. Lepot ${ }^{7}$, D. Munaron ${ }^{8}$, C. Tixier ${ }^{9}$, A Togola $^{3}$, \\ M. Coquery
}

${ }^{1}$ Irstea, UR MALY, 3 bis quai Chauveau, CP 220, 69336 Lyon, France

2 Irstea, UR REBX, 50 Avenue de Verdun, Gazinet, 33612 Cestas Cedex, France

${ }^{3}$ BRGM, MMA, 3 avenue Claude Guillemin, 45060 Orléans, Cedex 02, France

${ }^{4}$ Ecole des Mines d'Alès, 6 avenue de Clavières, 30319 Alès Cedex, France

5 Ifremer, BE, B.P.330, Zone Portuaire de Brégaillon, 83507 La Seyne/mer Cedex, France

${ }^{6}$ LNE, DMSI, 1 rue Gaston Boissier, 75724 Paris, Cedex 15, France

7 INERIS, Parc Technologique Alata, BP2, 60550 Verneuil-en-Halatte, France

${ }^{8}$ Ifremer, LERLR, avenue Jean Monnet, BP 171, 34203 Sète Cedex, France

${ }^{9}$ Ifremer, RBE-BE-LBCO, rue de l'lle d'Yeu, 44311 Nantes, Cedex 3, France

*: Corresponding author : Cécile Miège, email address : cecile.miege@irstea.fr

\begin{abstract}
:
An intercomparison exercise on passive samplers (PSs) was organized in summer 2010 to measure selected metals, polycyclic aromatic hydrocarbons (PAHs) and pesticides in surface waters. Various PSs were used and compared at two river sites and one marine lagoon. A total of 24 laboratories participated.

We present selected significant results from this exercise, including discussion on quality assurance and quality control for PSs, the interlaboratory variability of field blanks, time weighted average water concentrations and their uncertainties, the representativity of samples from Diffusive Gradient in Thin film, the ability of PSs to achieve lower limits of detection, PAH fingerprints in various PSs compared with spot samples, and the relevance of the permeability reference compound approach to the Polar Organic Chemical Integrative Sampler with pesticides.

These in situ intercomparison exercises should enable progress on the harmonization of practices for use of passive sampling, especially for priority chemical monitoring and regulatory programs in compliance with the European Union's Water Framework Directive and the Marine Strategy Framework Directive.
\end{abstract}

\section{Highlights}

We present the first results from an intercomparison exercise on passive samplers. We discuss quality control and quality assurance strategy. We discuss the interlaboratory time weighted average (TWA) water concentrations. Through examples, we present the scope of some passive samplers (DGT, POCIS and SPMD). $>$ We discuss the permeability reference compounds approach to POCIS and pesticides.

Keywords: Intercomparison exercise ; Marine Strategy Framework Directive (MSFD) ; Metal ; Passive sampling ; Pesticide ; Polar organic chemical integrative sampler (POCIS) ; Polycyclic aromatic hydrocarbon (PAH) ; Priority chemical ; Surface water ; Water Framework Directive (WFD)

\section{Introduction}

As defined by Allan, et al. [1], the possible functions of passive samplers (PSs) in the context of the Water Framework Directive (WFD) and Marine Strategy Framework Directive (MSFD) can be:

- measurement of time weighted average (TWA) water concentrations,

- assessment of spatial and temporal trends in level of pollutants, 
- screening of pollutant for presence or absence (with improved limits of detection and quantification, LODs and LOQs),

- speciation of contaminants,

- identification of sources of pollution, establishment of pressure-impacts relationships,

- integrated assessment of pollutant load across national boundaries.

As other emerging tools (biomarkers, biological early warning systems, bioassays/biosensors, chemical and electrochemical sensors, immunoassays), PSs should have a positive influence on the future design and output of monitoring programmes, improving level of confidence in monitoring data in comparison with conventional spot sampling [1].

However, passive sampling implementation by a non-expert public relies on mastering and understanding of their inherent capabilities and limitations. Therefore, the scientific community needs to clarify some points to allow these tools to be more widely used within monitoring programmes, such as the use of PRC (performance reference compounds), optimum exposure duration, influence of seasons and of biofouling and physico-chemical characteristics of aquatic systems on the pollutant accumulation and resulting TWA concentrations [2]. Another crucial point is to enable the use of passive sampling to contribute to the detection of peaks of concentrations during short but significant pollution events (e.g., flood events, storm events, accidental punctual loads of pollutant). Indeed, better knowledge is required on the lag observed between the appearance of a peak of contaminant concentration in water and its detection by a PS [1]. Quality assurance and control (QA/QC) procedures (validated and standardized methods), the demonstration of comparability with existing methods and further validation of calibration procedures are also required. Because of the difficulty to develop certified passive samplers, there is a need for new QA/QC approaches; this could involve the use of reference sites or the need of interlaboratory exercises. Also, as there is a large diversity of commercially available as well as home-made PSs, it is necessary to put in perspective which PS is suitable for a given application. Eventually, since the pollutant fraction sampled by PSs could be different from that measured using spot sampling, it might be important to rethink the definition of WFD Quality Standards (EQSs) to be compared with the PS data [3, 4].

Hence, there is a need for organizing intercomparison exercises, including codeployments of different PSs in waters, to help the scientific community to find the best solutions on still unanswered crucial questions [2]. Very few in situ intercomparison exercises on PSs have been performed until now. Allan et al., [5] tested the performance of 7 PSs (non polar Chemcatcher, low density polyethylene membranes - LDPE, 2 versions of membrane enclosed sorptive coating - MESCO, silicone rubber SR (i.e. PDMS sheet), and semi permeable membrane device SPMD) for the monitoring of polycyclic aromatic hydrocarbons (PAHs), polychlorinated biphenyls (PCBs), hexachlorobenzene and dichlorodiphenyldichloroethylene (p,p'-DDE) in the river Meuse (The Netherlands). They compared PRCs rate of dissipation, mass of analytes accumulated and TWA, concentrations. Despite different methods of calculation, relatively consistent TWA concentrations were obtained (standard deviation of log-transformed TWA concentration varying up to 2 units). Through the comparison with institutional WFD monitoring (i.e., spot sampling 12 times per year) and with EQSs, Allan et al., [5] concluded on the usefulness of the TWA concentration obtained with all tested PSs for all studied pollutants. Lohman et al. [2] recently suggested to use PSs (with a preference for LDPE) for monitoring persistent organic pollutants (POPs) as a global tool at background sites instead of sentinel biological species. In situ, the use of PSs ensured statistically comparable results. They allowed to obtain enrichment factors of POPs up to $10^{4}$ compared with spot waters samples [2]. To our knowledge, no results on intercomparison exercise have been published to date on POCIS (Polar Organic Chemical Integrative Sampler). The use of Diffusive Gradient in Thin Film (DGT) and Chemcatcher (configured for metals) provided robust mapping of metal concentration in the 
Aller river system (basin of the River Weser, North Germany), characterized by marked spatial variations [6]. It proved also promising for monitoring long term changes in metal concentration, by reducing the error associated with environmental variability when compared with spot sampling on a monthly basis. TWA concentrations for the 2 PSs were consistent for all metals tested $(\mathrm{Ni}, \mathrm{Cu}, \mathrm{Zn}, \mathrm{Cd}$ and $\mathrm{Pb}$ ), with the exception of $\mathrm{Pb}$, for which Chemcatcher calibrations were associated with high uncertainties (TWA concentration with RSD up to $100 \%$ ). It is hazardous to compare TWA concentrations for metal concentrations with spot sampling, since they concern different fractions of dissolved metals (total dissolved versus labile fraction, respectively). Nevertheless, a very good agreement was found between TWA concentrations and dissolved $\mathrm{Cd}$ and $\mathrm{Zn}$ concentrations determined with spot sampling on the Meuse River (Netherlands) [1], while PSs systematically underestimated filtered concentration of metals (Cd, $\mathrm{Cu}, \mathrm{Zn}, \mathrm{Pb}$, and $\mathrm{Ni}$ ) on the Oker and Aller river (Germany) [6].

In the context of a scientific collaboration between expert laboratories, an intercomparison exercise on various PSs was organized in summer 2010 by French public institutions belonging to the French reference laboratory for water monitoring, AQUAREF (www.aquaref.fr). The general objective of this study was to assess the potential function and the efficiency of PSs for priority pollutants monitoring in surface and coastal waters in the context of the WFD and MSFD. More specifically, the goals were: (i) to evaluate the comparability and variability of measurements of selected priority substances with PSs, (ii) to evaluate the suitability of these samplers implemented in different aquatic environments to sample selected substances, and (iii) to demonstrate the applicability of such tools to water basin managers and routine laboratories. Since various types of PSs are available, there is no detailed guideline for their use and such tools are not mastered by routine laboratories, this intercomparison exercise was only proposed to laboratories already experimented with at least one type of PS; and this exercise was conducted by letting these expert laboratories perform as they were used to. Hence, we let participants implement their known PSs, using their own methodology/approach for the deployment, the analytical treatment and the calculation of TWA concentrations.

In this paper, we present selected significant outputs from this exercise, including the information on the various analytical and data treatment strategies followed by participants to obtain TWA concentration; we also discuss on QA/QC procedures for PSs, the interlaboratory variability of PS field blanks, TWA concentrations and its uncertainty, the representativity of DGT samples, the ability of PSs to improve LOQs, PAH fingerprints in various PSs and compared with spot samples, and the relevance of the PRC approach for POCIS with pesticides.

\section{Experimental section}

24 expert laboratories with various exposure and analytical strategies and PSs:

24 laboratories participated to this intercomparison exercise: ALS Scandinavia AB (SW), AZTIFoundation (ES), BRGM (FR), Cefas (UK), Irstea/Cemagref (FR, of Bordeaux, Lyon and Paris), Deltares/TNO (NL), Ecole des Mines d'Alès (FR), EDF R\&D/LNHE (FR), Environment Agency, National Laboratory Service (UK), IFREMER (FR, of Nantes, Sète and Toulon), Labaqua (ES), LEESU (FR), EPOC-LPTC (FR), Marine Scotland - Science (UK), NIVA (NO), T. G. Masaryk Water Research Institute, Public Research Institution (CZ), UFZ - Department of Ecological Chemistry, Helmholtz Centre for Environmental Research (DE), University of Cagliari (IT), University of Rhode Island (USA) and Water Research Institute (SK). 
The tested PSs were the following: POCIS, SPMD, membranes (LDPE, SR), SBSE (Stir Bar Sorptive Extraction), polar and non polar Chemcatcher, MESCO (Membrane-Enclosed Sorptive Coating) for organic contaminants; and DGT and Chemcatcher for metals.

Each laboratory was asked to implement its studied PSs using its own methodology/approach for the deployment, the analytical treatment and the calculation of TWA concentrations. The various strategies and PSs used are summarized in Table 1.

\section{Technical prescriptions:}

32 target substances:

We studied 32 molecules among which 8 metals $(\mathrm{Cd}, \mathrm{Ni}, \mathrm{Pb}, \mathrm{Zn}, \mathrm{Cu}, \mathrm{Mn}, \mathrm{Co}, \mathrm{Cr})$; the $16 \mathrm{EPA}$ priority PAHs (naphthalene, acenaphthene, acenaphthylene, anthracene, phenanthrene, pyrene, fluoranthene, fluorene, benzo(a)pyrene, chrysene, benz(a)anthracene, benzo(b)fluoranthene, benzo(k)fluoranthene, benzo(g,h,i)perylene, dibenz(a,h)anthracene, indeno(1,2,3-cd)pyrene); and 9 pesticides (acetochlor, S-metolachlor, 5 WFD priority substances, i.e., alachlor, atrazine, diuron, isoproturon, simazine and 2 atrazine metabolites, i.e., desethylatrazine, deisopropylatrazine).

\section{Planning, sites and exposure strategy:}

Trials were conducted on 2 rivers, the Charente River, Beillant, France, from 27th of May to 10th of June and the Rhône River, Ternay, France, from 17th of June to 8th of July; and at one marine site, the Thau Lagoon, Hérault, France, from 27th of April to 18th of May.

Sampling campaigns were organized for the measurement of metals at Thau and Ternay sites, PAHs at Thau and Ternay sites, and pesticides at Thau and Beillant sites. Exposure durations were set at 7 days for metals, 14 days for pesticides and 21 days for PAHs.

PSs were exposed in triplicates and field blanks (i.e., PS brought to the field but not exposed in waters) were used. A reference standard solution (QC solution) was used to evaluate the accuracy and uncertainty of the analytical step. Because of the design of the trial, implementation of QC based on reference PSs (spiked and then distributed to all participants) was not technically possible (too many different PSs studied).

For metals, the reference values in the QC solution for the elements $\mathrm{Cd}, \mathrm{Cr}, \mathrm{Cu}, \mathrm{Ni}, \mathrm{Pb}$ and $\mathrm{Zn}$ were obtained by the method of isotope dilution ( 2 isotopes/metal). This method is not applicable to $\mathrm{Mn}$ and $\mathrm{Co}$ as they only have one isotope; for those metals, the standard addition method was used. The implemented instrumental technique was ICP-MS. The uncertainty corresponds to the uncertainty of the analytical method implemented and the repeatability of the measurement process. The stability of prepared solutions (assessed over the entire test period, 4 months) was tested and changes in concentration found negligible; thus, it was not taken into account.

The reference values of concentrations for PAHs and pesticides (see the list of target molecules in Table 2) in the QC solution have been certified thanks to the method of isotopic dilution associated to gas chromatography coupled to mass spectrometry (ID / GC-MS) for PAHs, and liquid chromatography coupled to tandem mass spectrometry (ID / LC-MS-MS) for pesticides, as well as strong metrological procedures. When possible, the achievement of traceability was performed by the implementation of certified reference materials (for PAHs: SRM 1647e, SRM 1597; for atrazine: GBW (E) 060615). Reference values and associated uncertainties were attributed to each PAH and pesticide considering the analytical uncertainty, the inter vials uncertainty and the uncertainty associated to sample instability (assessed over the entire test period, 4 months). 
To enable the comparison of integrative sampling with spot sampling, 6 central laboratories were in charge of the analysis of target molecules in spot surface water samples collected at regular intervals during the campaigns. Moreover, to enable a thorough interpretation of passive sampling results, physico-chemical parameters (i.e., $\mathrm{pH}$, suspended matter, ionic composition, conductivity, dissolved and total organic carbon, temperature, water velocity, pluviometry, water flow; and also dissolved oxygen and salinity for Thau only) were determined in surface waters at each studied site. These data are compiled and available in Supplementary material.

\section{Statistical data treatment:}

The methodology applied for the QC solution is the robust statistical method according to ISO standard 5725-5 [7]. The principle of this method is to calculate statistical parameters from all participants data (i.e., no outlier is eliminated from the dataset even if the data could be considered as outliers by Cochran or Grubbs tests). Such statistics are based on the population ranks and are more suitable for small populations and a limited number of replicates. They consider all the data, with a minimization of the weight for outliers. As a result, a robust mean value and its uncertainty are provided for each substance.

Various statistical treatments were applied and compared on the TWA concentration data obtained with exposed PSs. Indeed, we calculated mean and standard deviation, obtained with (i) classical method, according to ISO standard 5725-2 [8], on all data (no outlier eliminated); (ii) classical method, according to ISO standard 5725-2 [8], on data after elimination of outliers identified by Cochran and Grubbs tests on QC data; (iii) robust method (no outlier eliminated) according to ISO standard 5725-5 [7]. Pearson test was processed to compare DGT based TWA concentrations from each laboratory with their respective field blanks concentrations. MannWithney test $(\mathrm{p}=0.05)$ was processed to compare TWA concentrations of diuron at Thau obtained with POCIS with the use or not of deisopropylatrazine- $d 5$ (DIA- $d 5$ ) as PRC.

\section{Results and discussions}

In the following parts, we present selected meaningful results that allow to put in light several crucial questions still unanswered, to illustrate advantages and drawbacks of passive samplers and to define their potential, especially for priority chemical monitoring and regulatory programs in compliance with the WFD and MSFD.

Results on laboratory quality controls and discussion on QA/QC procedure for PS:

Results from statistical treatment on QC data for PAHs and metals at Ternay site, and for pesticides at Beillant site are compiled in Table 2.

Accuracy can be evaluated for each substance by the equation: (robust mean value x 100) / reference value (data not shown in Table 2). When comparing the reference value obtained on the QC solution with the robust mean (and the associated uncertainty), we note that accuracy and uncertainty of measurements were better for metals analysis than for organic molecules analysis. For metals, accuracy varied from $91 \%$ for Ni to $123 \%$ for $\mathrm{Zn}$. Nonetheless, for metals, the most critical pollutants were $\mathrm{Zn}, \mathrm{Cr}$ and $\mathrm{Ni}$ (with relative standard deviations on robust mean - RSDof 24, 22 and 16\%, respectively). For organic molecules, accuracy varied from $98 \%$ for deisopropylatrazine and isoproturon to $141 \%$ for acetochlor. RSD on robust mean ranged from 17 to $47 \%$, with higher values for atrazine, simazine, benzo(g,h,i)perylene and indeno(1,2,3cd)pyrene. For some compounds such as atrazine, acetochlor, benzo(a)pyrene, zinc, a lack of accuracy was shown (no overlap between the reference value \pm uncertainty and the robust mean \pm uncertainty). Yet, no relationship could be found between the quality of measurement, the analytical methods and the quantification approach implemented. 
The implementation of QCs such as reference solution (or reference value) for the evaluation of instrumental analysis is needed when organizing intercomparison exercises to ensure the basis of the comparability of measurements. However, it is clear that those are not sufficient and that reference or certified PSs would still be needed to take into account the overall laboratory aspects for PSs analysis (i.e., conservation, extraction, purification and analytical steps). Because of the specificities of PSs approaches, new QA/QC procedures need to be proposed to take into account the field deployment steps.

\section{Discussion on PS field blanks:}

For some metals, DGT field blanks showed a great variability between the participants. Indeed, at Ternay site, several participants reported field blanks in the same range or above robust TWA concentrations for $\mathrm{Cd}, \mathrm{Cr}$ and $\mathrm{Zn}$ (Figure 1); also at Thau site, for several participants, fields blanks were in the same range or above TWA concentrations for $\mathrm{Cr}, \mathrm{Pb}$ and $\mathrm{Ni}$ (data not shown). Despite this high contribution of field blanks compared with TWA concentrations, only two laboratories at Ternay and one at Thau subtracted field blanks from TWA concentrations. Besides, the comparison between TWA concentrations from each laboratory with their respective field blanks concentrations (Figure 1) showed a significant positive linear relation for $\mathrm{Cr}(\mathrm{r}=0.78, \mathrm{p}<0.05)$ and for $\mathrm{Zn}(\mathrm{r}=0.84, \mathrm{p}<0.05)$ at Ternay. Despite a smaller data set $(\mathrm{n}=5)$ at Thau site, a significant positive linear relation was also found between field blanks and TWA concentration for $\mathrm{Ni}(\mathrm{r}=0.98, \mathrm{p}<0.05)$ and $\mathrm{Cr}(\mathrm{r}=0.99, \mathrm{p}<0.05)$. This suggests that for these metals, contaminated field blanks are partly responsible for the uncertainty of TWA concentrations.

For organic contaminants (data not shown), the situation for field blanks appeared highly contrasted. Concentrations of pesticides measured in all field blanks were below limits of quantification. For PAHs, blank results depended on the nature of PAH, the laboratory and the site. For instance, the concentrations of benzo(k)fluoranthene, chrysene and anthracene measured in field blanks were homogeneous and non significant (i.e., background contamination) at both sites; quite the opposite, those of phenanthrene, naphthalene, pyrene and benzo(a)pyrene might represent up to $90 \%$ of the TWA concentrations, and in some cases, it may exceed it (up to 8 times for 1 laboratory with naphthalene at Thau). At this stage, no clear relationship with the type of PS, the site, the laboratory, the analytical methodology or the laboratory accuracy (as evaluated by the QC standard solution) could explain this contamination.

As laboratory blank results were not specified by the participants; we cannot check if the observed contamination of field blanks originated from laboratory steps or from field exposure. In further studies, data treatment on both laboratory blanks and field blanks would allow to assess the contamination origin. Nonetheless, these results demonstrated that PS manipulation is critical for some metals (i.e. $\mathrm{Cd}, \mathrm{Cr}, \mathrm{Pb}$ and $\mathrm{Zn}$ ) and PAHs (i.e. phenanthrene, naphthalene, pyrene and benzo(a)pyrene), requiring to work in very clean conditions in order to not compromise micropollutant measurements in surface waters via passive sampling.

\section{Evaluation of TWA concentration with PSs: \\ Statistical data treatment:}

Results on mean and standard deviation of TWA concentration concerning PAH and metals at Ternay, and pesticides at Beillant (all PSs considered together for each chemical family/site) are reported on Figure 2 and in Table 3 (columns 2 to 7).

As shown on Figure 2, calculated TWA concentration means and standard deviations for PAHs, metals and pesticides are quite similar when using data from all participants or only data obtained after elimination of laboratories displaying QC outliers (e.g., 3 participants among 12 
were not considered for atrazine/POCIS). In contrast, except for naphthalene and diuron, the robust statistical approach tends to decrease TWA concentration means and standard deviations. For the rest of this part, and because it is more suitable for small populations, we chose to use robust statistical treatment (no outlier eliminated).

TWA concentrations of PAHs, pesticides and metals (whatever the PS):

At Ternay, for metals, the RSD of TWA concentration after robust statistic approach were below $79 \%$, except for $\mathrm{Cr}(93 \%)$ and $\mathrm{Pb}(112 \%)$ (Table 3, column 6). For organic micropollutants, RSD were lower than 104\%, except for acenaphthylene (130\%), atrazine (111\%) and desethylatrazine $(111 \%)$. These results are very satisfying considering the various PS tools, laboratories, analytical strategies, and the higher analytical uncertainties generally observed for organic than for inorganic micropollutants. Unfortunately, it is difficult to discriminate the variability origin (analytical, PS tool or method for TWA concentration calculation) responsible for the higher uncertainty obtained for $\mathrm{Cr}, \mathrm{Pb}$, acenaphthylene, atrazine and desethylatrazine. At Thau, RSD were similar for most substances $(<77 \%$ for metals, $<104 \%$ for organics) but higher values were observed for $\mathrm{Zn}$ (85 \%), Cd (92 \%), acenaphthylene (149\%) and indeno(1,2,3-cd)pyrene (112\%).

At Ternay, TWA concentration of metals decreased in the following order: $\mathrm{Mn}>\mathrm{Zn}>\mathrm{Ni}, \mathrm{Cu}>$ $\mathrm{Cr}, \mathrm{Pb}>\mathrm{Co}>\mathrm{Cd}$. TWA concentrations obtained by robust statistical approach ranged from $3.48 \mu \mathrm{g} / \mathrm{L}$ for $\mathrm{Mn}$ to $0.005 \mu \mathrm{g} / \mathrm{L}$ for $\mathrm{Cd}$. At Thau site, TWA concentrations were similar, except for $\mathrm{Cd}$ that showed higher TWA concentration $(0.021 \mu \mathrm{g} / \mathrm{L})$; this was probably linked to $\mathrm{Cd}$ desorption from particulate phase and chloro-complexation in dissolved phase within the lagoon (high salinity). For organic micropollutants, TWA concentration ranged from 0.4 to $36 \mathrm{ng} / \mathrm{L}$ for isoproturon and desethylatrazine at Beillant, from 0.008 to $9.5 \mathrm{ng} / \mathrm{L}$ for dibenz(a,h)anthracene and naphthalene at Ternay, and TWA concentration were below $2 \mathrm{ng} / \mathrm{L}$ for PAHs at Thau.

Comparison of TWA concentration with concentration obtained with spot sampling must be cautiously done. This will be further discussed in the following parts. Anyway, the robust means and standard deviations of TWA concentration obtained with the PSs were comparable to the results obtained with the average spot sampling concentrations (Table 3). Such results highlight the interest of passive sampling techniques for the ultra-trace analysis of the selected pollutants.

Comparison of TWA concentrations according to the type of PS:

Figure 3 presents the TWA concentrations obtained for each laboratory and compared with the robust mean TWA concentrations obtained from all laboratories. This figure also displays outlier laboratories identified by Grubbs or Cochran tests for QC and TWA concentration data.

For PAHs at Ternay site, the robust mean TWA concentration obtained with SPMD was most of the time higher (but in the same range of concentration, except for acenaphthylene) than the robust mean TWA concentration calculated using all PSs data (Table 3). This can be explained by significant higher TWA concentrations obtained with SPMD for a group of 3 to 4 laboratories. Indeed, among the 12 participants using SPMD to quantify fluoranthene, the results of 3 of them were not within the robust mean TWA concentration \pm standard deviation interval (Figure 3A); similarly, 2 participants among 10 reported values outside the robust mean interval for benzo(a)pyrene (Figure 3B). Three participants using SR and 5 participants using LDPE reported satisfying results for fluoranthene and benzo(a)pyrene.

Concerning pesticides, some outliers were identified for the passive sampling of atrazine (Figure 3C) and metolachlor (Figure 3D) at the site of Beillant. Indeed, according to Cochran test, a high variability was observed for these 2 pesticides for the participant using SR. Hence, SR did 
not appear suitable for the passive sampling of polar chemicals; this observation is in good agreement with the theoretical sampling range of devices based on PDMS material [9-11]. Moreover, the robust means considering only the POCIS results were very close to those calculated for all PSs (idem for the associated standard deviations), (Table 3). All these pesticides are hydrophilic (i.e., $\log \mathrm{K}_{\mathrm{ow}} \leq 3.2$ ) and these results are consistent with the expected performances of POCIS [12-14]. To note, most participants used the POCIS with pharmaceutical configuration (i.e., Oasis HLB sorbent as receiving phase).

Results obtained on metals with DGT "open pore" and "restrictive" showed similar TWA concentrations at Ternay and Thau sites. Indeed, calculated concentrations from the 2 "restrictive" DGT were included within the uncertainty of the results reported with DGT "open pore". Therefore, this suggests that (i) these two kinds of DGT did not allow discriminating labile metals and metals complexed with large colloids, or (ii) these metals were mainly represented by inorganic metal forms and by small inorganic or organic complexes at the 2 sites. In most cases, TWA concentrations, which were significantly higher for 2 or 3 laboratories (e.g., $\mathrm{Cd}$ and $\mathrm{Pb}$, Figure 3), were linked to a higher variability of the measurement (DGT triplicates). In other cases (i.e., $\mathrm{Mn}, \mathrm{Co}, \mathrm{Cu}, \mathrm{Ni}, \mathrm{Zn}$ and $\mathrm{Cr}$ ), higher TWA concentrations could be linked to analytical problems, as identified by QC outliers. Some of the variability might originate from insufficient blank control. At Ternay site, only one participant deployed a Chemcatcher. This participant reported results for $\mathrm{Cd}, \mathrm{Pb}, \mathrm{Zn}$ and $\mathrm{Ni}$ only, and TWA concentrations were often higher than TWA concentrations obtained with DGT sampling. Despite satisfying QC results for this laboratory and because of a lack of comparison data for Chemcatcher, it is not possible to conclude on the relevance of Chemcatcher compared to DGT to measure metals in aquatic environments. No Chemcatcher were deployed at Thau site.

To conclude on the evaluation of TWA concentrations, it is difficult to statistically compare the performances of the various PS because each PS was not represented by the same number of laboratories. Nonetheless, all PSs allowed to obtain TWA concentrations with an uncertainty generally below $100 \%$, which is very satisfying considering the low micropollutant concentration levels, the diversity of PSs, laboratories, and measurement (sampling and analytical) strategies.

Comparison of concentration uncertainties obtained with passive sampling and with spot sampling - the example of pesticides with POCIS:

As reported by Allan et al. [1], the evaluation of uncertainties for contaminant concentrations is generally only based on the sample extraction and analytical procedure, and does not take into account the sampling steps. Furthermore, uncertainties associated with PS technique are not really documented. The vast majority of studies related to PS of polar chemicals mentioned the use of replicates $(\mathrm{n}=2,3$ or 5$)$ during laboratory calibrations or in situ deployments $[12,14,16$ 18]. However, it is regrettable to note that the uncertainty evaluation is reduced to the calculation of standard deviations only. Besides, RSDs reported in different studies are highly variable, ranging from about $20-30 \%[12,19]$ to $150 \%$ [14, 20, 21] for polar chemicals and devices like POCIS and Chemcatchers.

For the first time, this intercalibration study provided some interesting results as regard to the uncertainties of the TWA concentrations obtained with various PSs for various pollutants including several polar pesticides. The uncertainties, expressed as robust reproducibility RSDs, ranged from 36 to $111 \%$ for pesticides with all PSs (Tables 3 and 4). Also, we reported in Table 4 the expanded uncertainties obtained for a classical proficiency testing [15] performed using freshwater spiked with selected pesticides (i.e., alachlor, atrazine, diuron, isoproturon and simazine). The comparison between the two sets of data showed a higher uncertainty for some 
analytes (i.e. alachlor, atrazine and simazine) sampled by PSs at Beillant. This higher uncertainty could be explained by the combination of field sampling, preconcentration and analytical steps for the PSs. In addition, we have to consider the variety of tools deployed during this study (cf., Table 1), home-made or commercial configurations, and the different calibration data and methodologies used for the calculation of TWA concentrations. Lastly, the comparison is delicate for some analytes due to the very small population size (e.g. $\mathrm{n}=2$ for alachlor).

Similar results were found for PAHs and metals. Thus, to conclude, when compared with the interlaboratory uncertainty due to the analysis step (without sampling), the uncertainty of measurement obtained with PSs is satisfying considering the ultra-trace level concentration of the selected pollutants.

Discussion on the fraction sampled and the representativity of the samples- the example of metals with DGT:

At Ternay site, TWA concentration of metals calculated from DGT deployment were systematically lower than spot sampling concentrations (Figure 3, Table 3). This suggests that DGT measured only a part of total dissolved metal concentrations, represented by labile forms (inorganic complexes and small inorganic or organic complexed metals). Indeed, total dissolved Mn was mainly represented by labile forms $(96 \%)$, while $\mathrm{Pb}$ was the metal the most complexed by non labile forms (only 17\% as labile forms). More precisely, for this freshwater environment, the lability of trace metal decreased in the following order: $\mathrm{Mn}>\mathrm{Zn}>\mathrm{Ni}>\mathrm{Cr}>\mathrm{Cd}>\mathrm{Cu}>\mathrm{Co}>$ $\mathrm{Pb}$.

At Thau site, due to a saline matrix, analysis of total dissolved metals in spot samples could not be done for $\mathrm{Cr}$ and $\mathrm{Mn}$. TWA concentrations obtained with DGT for Cd $(0.027 \mu \mathrm{g} / \mathrm{L})$ and $\mathrm{Zn}$ $(3.15 \mu \mathrm{g} / \mathrm{L})$ were 2 and 5 fold higher than spot sampling concentrations $(0.014 \mu \mathrm{g} / \mathrm{L}$ and 0.666 $\mu \mathrm{g} / \mathrm{L}$, respectively) (data not shown). Moreover, contribution of labile metals to total dissolved metals were much higher at Thau than at Ternay site, ranging between $470 \%$ for $\mathrm{Zn}$ and $27 \%$ for $\mathrm{Cu}$. This could probably be due to a storm event (strong wind without rainfall) which occurred during PSs deployment, and that might have induced trace metal remobilisation via sediment resuspension. Therefore, PSs recorded a locally and temporary increase of trace metal concentrations in the water column, while spot sampling (performed on 3 different days, and not during the storm event) did not.

To conclude, the question of the passive sampling representativity (i.e., the water fraction dissolved $v s$. bulk, and labile dissolved forms vs. total dissolved for metals-, and the integration of pollution with time) need to be clarified and clearly stated to allow the implementation of these PSs in the framework of the WFD and MSFD.

Do passive sampling allow to decrease LOQ when compared with spot sampling?

We know that water concentration with spot sampling cannot be strictly compared with TWA concentration (i.e., the water column fraction sampled is not the same and spot sampling does not represent time integrative sampling). Nonetheless, some PAHs at Ternay were quantified in SPMD, LDPE, SR, non polar Chemcatcher and CFIS, whereas they were below the LOQ in the dissolved fraction of spot samples (i.e., benzo(a)pyrene, benzo(b and k)fluoranthene, dibenz(a,h)anthracene, benzo(g,h,i)perylene). From Table 3, we observe that LOQ with spot sampling decreased when using SPMD by a factor of 2 for benzo(a)pyrene, benzo(k)fluoranthene and benzo(g,h,i)perylene, and by a factor of 7, 16 and 24 for indeno(1,2,3cd)pyrene, acenaphthylene and dibenz(a,h)anthracene, respectively. Similarly, passive sampling of pesticides with POCIS, polar Chemcatchers and SR allowed to significantly decrease the LOQs. For example, only desethylatrazine (DEA), deisopropylatrazine (DIA) and metolachlor 
were quantified with spot sampling, whereas POCIS allowed to quantify all of the 9 studied pesticides (Table 3). Concerning metals, passive sampling did not allow to quantify more targeted micropollutants than with spot sampling.

To conclude, the LOQs generally decreased when using PSs in comparison with spot sampling; this decrease depends mainly upon the type of PS, the micropollutant and exposure conditions.

Comparison of PAH fingerprint for various PSs:

Fingerprints of the 16 PAHs obtained at Ternay with SPMD, LDPE, SR, non polar Chemcatcher, CFIS and spot samples (bulk and dissolved water fractions) are illustrated on Figure 4. Fingerprints are reported only for the laboratories which analysed the 16 PAHs and obtained satisfying QC results according to Cochran and Grubbs tests. LDPE and SR showed very similar fingerprints; both PSs tend to better accumulate the higher molecular weight PAHs when compared with Chemcatcher, CFIS and, to a lesser extent, with SPMD. Moreover, these 5 PAHs (from benzo(b)fluoranthene to dibenz(a,h)anthracene) did not accumulate at all in Chemcatcher and could not be quantified in spot water samples (dissolved phase), whereas they were generally quantified in the 4 other PSs.

To conclude, micropollutants fingerprints differed according to the type of PS used; they also varied when comparing PS data with classical spot sampling of waters (bulk or dissolved fraction). It is necessary to take this into account when one intends to use PS for monitoring programs (e.g., to select the PS best adapted to the nature of micropollutants monitored).

Relevance of the PRC approach with POCIS for pesticides:

For pesticides, only a few data were obtained at Thau site due to the very low concentrations $(<1$ ng. $\mathrm{L}^{-1}$ ) which were quantified by a limited number of participants. For instance, diuron was one of the most quantified pesticide, with results provided by 4 participants (Figure 5). It must be noted that 2 participants used POCIS-HLB spiked with DIA- $d 5$ as PRC. Initially, only one participant reported the robust mean and standard deviation of the TWA concentration $(7.5 \pm 6.8$ ng. $\mathrm{L}^{-1}$ ) using the PRC correction. In this case, a significant difference of the TWA concentration between the 2 sets of POCIS was observed (Figure 5, white and grey histograms). Consequently, data were reinterpreted with the PRC correction (Figure 5, white histograms for the 2 participants using POCIS), resulting in a clear improvement of the data comparability for POCIS. Such an observation could indicate the relevance of the PRC approach for this type of device. A larger number of laboratories using POCIS participated in the exercise at Beillant $(n=9)$. However, as for Thau, only 2 of them used POCIS with a PRC. The conclusions are similar since the comparability of these 2 laboratories was improved with the application of the PRC correction. Nevertheless, the population means of the TWA concentrations (Table 3) were not really affected by the consideration of the PRC for these 2 participants. Thus, another intercomparison test performed with more PS replicates and a wider range of pesticides, as expected for the NORMAN interlaboratory study performed in 2011, might be more conclusive on this PRC issue.

To conclude, the PRC approach, which is more developed with membrane PSs (i.e. SPMD, LDPE, SR) than with solid phase PSs (i.e., POCIS, Chemcatcher) is a key strategy that needs further research in order to increase the reliability of TWA concentrations for organic micropollutants.

\section{Conclusion}


Considering the variety of expert laboratories, strategies and tools, we observed a low and satisfying uncertainty on the estimation of mean TWA concentrations with passive sampling. LOQs were generally significantly lower by using PSs when comparing with spot sampling (in particular with LDPE, SR and SPMD for PAHs, and POCIS for pesticides). Indeed, PSs allowed to quantify additional organic contaminants than conventional spot sampling (which was not the case for the targeted metals). The use of PRC with POCIS for pesticides appeared to improve TWA concentration comparability between laboratories. However a larger data set would be required for a thorough study on PRC. Furthermore, there is a need to better put in perspective which PS is suitable for a given application: for example, SR might not be best adapted for polar pesticides since they result in significantly different TWA concentration when compared with other PSs such as POCIS; considering PAH monitoring and fingerprint, the choice of PSs is crucial as they are more or less adapted for low or high molecular weight PAHs; the use of DGT at Thau allowed to record a local and temporary increase of trace metal concentrations in the water column, probably due to a storm event, while spot sampling did not. The fraction of water sampled with PSs needs to be clearly stated (dissolved vs. bulk; and labile dissolved forms $v s$. total dissolved for metals). However, special attention needs to be paid to field and laboratory blanks with PSs for some metals $(\mathrm{Cd}, \mathrm{Cr}, \mathrm{Pb}, \mathrm{Ni}$ and $\mathrm{Zn}$ ) and PAHs (phenanthrene, naphthalene, pyrene and benzo(a)pyrene). Indeed, insufficient blank control was probably responsible for some of the observed uncertainty of TWA concentrations of metals and PAHs in these exercises.

In order to enable a better use of PSs in the context of WFD and MSFD, we clearly identified the need of reference or certified PSs to enable laboratories to demonstrate and to improve their mastery during the PSs analytical treatment in laboratory (conservation, extraction, purification steps and analysis). Furthermore, new QA/QC procedures need to be proposed to take into account the field deployment. Finally, to extend their use to non expert laboratories, there is a strong need of more detailed protocols with description of blanks (laboratory and field), PRCs, $\mathrm{R}_{\mathrm{S}}$ and equations to use for the calculation of TWA concentration.

Today, PSs are still not used in some countries and especially in continental waters. Some operationals are still not convinced by their potentiality and they still do not master their limits. To promote PS on a long term and not to discredit them, we think it is necessary to clearly state what is working and what is still not working, and which PS to select for which objective. These in situ intercomparison exercises should enable to progress on the knowledge and harmonization of practices for the use of passive sampling, especially for priority chemical monitoring and regulatory programs in compliance with the WFD and MSFD. Further outputs of this work should follow, dealing with a thorough investigation of the source of TWA concentration uncertainty, more detailed comparisons between tools tested, etc.

\section{Acknowledgments}

The authors thank the French National Agency for Water and Aquatic Environments (ONEMA) via AQUAREF for its financial support.

The authors thank the central laboratories for water analysis: BRGM of Orléans (HAP), Irstea/Cemagref of Bordeaux (pesticides, physico-chemical parameters in Beillant site), Irstea/Cemagref of Lyon (metals, physico-chemical parameters in Ternay site), EPOC-LPTC of Bordeaux (pesticides and PAHs in Thau site), IFREMER of Sète (physico-chemical parameters in Thau site), IFREMER of Nantes (RBE/BE/LBCM) (metals in Thau site).

The authors especially thank the expert laboratories that participated to this intercomparison exercise: ALS Scandinavia AB (SW), AZTI-Foundation (ES), BRGM (FR), Cefas (UK), Irstea/Cemagref (FR, of Bordeaux, Lyon and Paris), Deltares/TNO (NL), Ecole des Mines 
d'Alès (FR), EDF R\&D/LNHE (FR), Environment Agency, National Laboratory Service (UK), IFREMER (FR, of Nantes, Sète and Toulon), Labaqua (ES), LEESU (FR), EPOC-LPTC (FR), Marine Scotland - Science (UK), NIVA (NO), T. G. Masaryk Water Research Institute, Public Research Institution (CZ), UFZ - Department of Ecological Chemistry, Helmholtz Centre for Environmental Research (DE), University of Cagliari (IT), University of Rhode Island (USA), Water Research Institute (SK).

\section{References}

[1] I.J. Allan, G.A. Mills, B. Vrana, J. Knutsson, A. Holmberg, N. Guigues, S. Laschi, A.-M. Fouillac, R. Greenwood, Trends in Analytical Chemistry, 25 (2006) 704.

[2] R. Lohmann, D. Muir, Environ. Sci. Tech. 44 (2010) 860.

[3] G.A. Mills, R. Greenwood, C. Gonzalez, Trends Anal. Chem. 26 (2007) 450.

[4] R. Greenwood, G.A. Mills, B. Roig, Trends Anal. Chem. 26 (2007) 263.

[5] I.J. Allan, K. Booij, A. Paschke, B. Vrana, G. A. Mills, R. Greenwood, Environ. Sci. Tech. 43 (2009) 5383.

[6] B. Roig, C. Valat, C. Berho, I.J. Allan, N. Guigues, G. A. Mills, N. Ulitzur, R. Greenwood, Trends Anal. Chem. 26 (2007) 274.

[7] NF ISO 5725-5, Accuracy (trueness and precision) of measurement methods and results Part 5: Alternative methods for the determination of the precision of a standard measurement method (1988) 65.

[8] NF ISO 5725-2, Accuracy (trueness and precision) of measurement methods and results - Part 2: Basic method for the determination of repeatability and reproducibility of a standard measurement method (1994) 54.

[9] B. Vrana, I.J. Allan, R. Greenwood, G.A. Mills, E. Dominiak, K. Svensson, J. Knutsson, G. Morrison, Trends Anal. Chem. 24 (2005) 845.

[10] F. Stuer-Lauridsen, Environ. Pollut. 136 (2005) 503.

[11] T.P. Rusina, F. Smedes, J. Klanova, K. Booij, I. Holoubek, Chemosphere 68 (2007) 1344.

[12] N. Mazzella, J.-F. Dubernet, F. Delmas, J. Chromatogr. A 1154 (2007) 42.

[13] D.A. Alvarez, J.N. Huckins, J.D. Petty, T. Jones-Lepp, F. Stuer-Lauridsen, D.T. Getting, J.P. Goddard, A. Gravell, G.M.a.B.V. R. Greenwood, in Comprehensive Analytical Chemistry, Elsevier, (2007) 171.

[14] D.A. Alvarez, J.D. Petty, J.N. Huckins, T.L. Jones-Lepp, D.T. Getting, J.P. Goddard, S.E. Manahan, Environ. Toxicol. Chem. 23 (2004) 1640.

[15] Deliverable 19 Part 2. Evaluation Report, 3rd SWIFT-WFD Proficiency Testing Schemes (2006), 260 pages.

[16] N. Mazzella, S. Lissalde, S. Moreira, F. Delmas, P. Mazellier, J.N. Huckins, Environ. Sci. Technol. 44 (2010) 1713.

[17] M. Shaw, G. Eaglesham, J.F. Mueller, Chemosphere 75 (2009) 1.

[18] H. Li, P.A. Helm, G. Paterson, C.D. Metcalfe, Chemosphere 83 (2011) 271.

[19] R. Gunold, R.B. Schäfer, A. Paschke, G. Schüürmann, M. Liess, Environ. Pollut. 155 (2008) 52.

[20] R.B. Schäfer, A. Paschke, M. Liess, Journal of Chromatography A 1203 (2008) 1.

[21] D.A. Alvarez, P.E. Stackelberg, J.D. Petty, J.N. Huckins, E.T. Furlong, S.D. Zaugg, M.T. Meyer, Chemosphere 61 (2005) 610. 
Tables

Table 1: Summary of type of PSs and exposure system, quality controls, calibration data and analytical steps used by participants for the 3 classes of studied substances.

\begin{tabular}{|c|c|c|c|c|c|c|c|c|}
\hline \multirow[b]{2}{*}{ Substances } & \multirow[b]{2}{*}{ Exposure system } & \multirow[b]{2}{*}{ Tools and main characteristics } & \multirow[b]{2}{*}{ Quality Controls } & \multirow[b]{2}{*}{ Diffusion coefficient } & \multirow[b]{2}{*}{ PRC } & \multirow[b]{2}{*}{ Rs } & \multicolumn{2}{|c|}{ Analysis step } \\
\hline & & & & & & & Preparation & Analysis \\
\hline Metals & $\begin{array}{l}\text { Commercially } \\
\text { available or home } \\
\text { made }\end{array}$ & $\begin{array}{l}\text { * DGT: binding agent (Chelex-100) with open pore or restrictive } \\
\text { diffusive gels (thickness: } 0.8 \mathrm{~mm} \text { ) } \\
\text { * Chemcatcher (metals) }\end{array}$ & $\begin{array}{l}\text { * Field blank } \\
\text { imposed } \\
\text { * Passive sampler } \\
\text { blank or not } \\
\text { * Correction from } \\
\text { blanks or not }\end{array}$ & $\begin{array}{l}\text { * Provided by DGT } \\
\text { Research Ltd } \\
\text { (Lancaster, UK) }\end{array}$ & $\mathrm{N} / \mathrm{A}$ & $\mathrm{N} / \mathrm{A}$ & $\begin{array}{l}* \text { Elution with } \\
\text { nitric acid } \\
\text { (1M) }\end{array}$ & $\begin{array}{l}\text { * ICP-MS } \\
\text { * GF/AAS }\end{array}$ \\
\hline PAHs & $\begin{array}{l}\text { Commercially } \\
\text { available or home } \\
\text { made }\end{array}$ & $\begin{array}{l}\text { * SPMD: standard, } 460 \mathrm{~cm} 2 \\
\text { * LDPE: from } 390 \text { to } 490 \mathrm{~cm} 2 \\
\text { * Chemcatcher (apolar), C18:15,9 and } 17,4 \mathrm{~cm} 2 \\
\text { * SR (PDMS sheet): } 5,160 \text { et } 600 \mathrm{~cm} 2 \\
\text { * MESCO : LDPE membrane, silicone phase } \\
\text { * CFIS (PDMS) }\end{array}$ & $\begin{array}{l}\text { * Field blank } \\
\text { imposed, } \\
\text { * Passive sampler } \\
\text { blank or not } \\
\text { * Internal surrogates } \\
\text { or not } \\
\text { * Correction from } \\
\text { field blanks or not }\end{array}$ & $\mathrm{N} / \mathrm{A}$ & $\begin{array}{l}\text { PRC used or not. } \\
\text { When information available: } \\
\text { D10A cenaphthene, } \\
\text { D10Fluorene, } \\
\text { D10Phenanthrene, } \\
\text { D12Chrysene, } \\
\text { D10Anthracene, D10Pyrene, } \\
\text { D12Benzo(a)pyrene, } \\
\text { D10Fluoranthene, } \\
\text { D14Dibenz(a,h)anthracene }\end{array}$ & $\begin{array}{l}\text { * From } \\
\text { literature or } \\
\text { determined by } \\
\text { the participant } \\
\text { * Various } \\
\text { models } \\
\text { applied }\end{array}$ & or not & $\begin{array}{l}\text { * GC-MS } \\
\text { * GCMMS/MS } \\
\text { * HPLC/Fluo }\end{array}$ \\
\hline Pesticides & $\begin{array}{l}\text { Commercially } \\
\text { available or home } \\
\text { made }\end{array}$ & $\begin{array}{l}\text { * POCIS: both pesticide and pharmaceutical configurations } \\
\text { * Chemcatchers (polar), C18, SDB-XC and SDB-RPS: } 15,9 \mathrm{~cm} 2 \\
\text { * SR (PDMS sheet): } 5 \mathrm{~cm} 2 \\
\text { * MESCO: cellulose membrane, silicone phase }\end{array}$ & $\begin{array}{l}\text { * Field blank } \\
\text { imposed, } \\
\text { * Passive sampler } \\
\text { blank or not } \\
\text { * Internal surrogates } \\
\text { or not } \\
\text { * Correction from } \\
\text { blanks or not }\end{array}$ & $\mathrm{N} / \mathrm{A}$ & $\begin{array}{l}\text { PRC (D5-deisopropylatrazine) } \\
\text { used by } \\
\text { only two particpants }\end{array}$ & $\begin{array}{l}\text { * From } \\
\text { literature or } \\
\text { determined by } \\
\text { the participant } \\
\text { * Various } \\
\text { models } \\
\text { applied }\end{array}$ & * Purification & $\begin{array}{l}* \text { GC-MS } \\
\text { * GC/MS/MS } \\
* \text { HPLC/MSMS }\end{array}$ \\
\hline
\end{tabular}

N/A: not available 
Table 2: Reference values with uncertainty and calculated robust means, uncertainty and standard deviations for the analysis of PAHs, pesticides and metals in the QC solutions ${ }^{1}$.

\begin{tabular}{|c|c|c|c|c|c|c|c|c|c|c|}
\hline \multirow[t]{2}{*}{ Site } & \multirow[t]{2}{*}{ Substances } & Reference value & $\begin{array}{c}\text { Uncertainty } \\
\text { reference value } \\
(k=1)\end{array}$ & Robust mean $x^{*}$ & $\begin{array}{c}\text { Standard } \\
\text { deviation on } \\
\text { robust mean }\end{array}$ & $\begin{array}{c}\text { Relative } \\
\text { standard } \\
\text { deviation on } \\
\text { robust mean } \\
\end{array}$ & $\begin{array}{c}\text { Uncertainty } \\
\text { robust mean } \\
\quad(k=1)\end{array}$ & $\begin{array}{c}\text { Reproducibility } \\
\text { standard } \\
\text { deviation } \\
S_{R} \\
\end{array}$ & $\begin{array}{c}\text { Repeatability } \\
\text { standard } \\
\text { deviation } \\
S_{r} \\
\end{array}$ & $\begin{array}{c}\text { Interlab. } \\
\text { standard } \\
\text { deviation } \\
S_{L} \\
\end{array}$ \\
\hline & & \multicolumn{2}{|c|}{$\begin{array}{c}\mu g / m L \text { for organics and } \mu g / L \text { for } \\
\text { metals }\end{array}$} & \multicolumn{2}{|c|}{$\begin{array}{c}\mu g / m L \text { for organics and } \mu g / L \text { for } \\
\text { metals }\end{array}$} & $\%$ & \multicolumn{4}{|c|}{$\mu g / m L$ for organics and $\mu g / L$ for metals } \\
\hline \multirow{10}{*}{ Ternay } & Benzo(a)pyrene & 1.867 & 0.022 & 2.181 & 0.652 & 30 & 0.22 & 0.66 & 0.12 & 0.65 \\
\hline & Benzo(b)fluoranthene & 1.993 & 0.015 & 2.151 & 0.581 & 27 & 0.21 & 0.59 & 0.14 & 0.58 \\
\hline & Benzo(k)fluoranthene & 1.930 & 0.020 & 2.165 & 0.515 & 24 & 0.18 & 0.52 & 0.11 & 0.51 \\
\hline & Indeno(1,2,3-c,d)pyrene & 1.730 & 0.295 & 2.047 & 0.943 & 46 & 0.30 & 0.95 & 0.09 & 0.94 \\
\hline & Acenaphthene & 1.937 & 0.015 & 1.959 & 0.388 & 20 & 0.12 & 0.39 & 0.05 & 0.39 \\
\hline & Anthracene & 1.930 & 0.060 & 1.907 & 0.349 & 18 & 0.11 & 0.35 & 0.06 & 0.35 \\
\hline & Benzo(g,h,i)perylene & 1.880 & 0.040 & 2.110 & 0.988 & 47 & 0.31 & 0.99 & 0.12 & 0.99 \\
\hline & Fluoranthene & 1.965 & 0.015 & 1.966 & 0.340 & 17 & 0.10 & 0.35 & 0.07 & 0.34 \\
\hline & Fluorene & 1.928 & 0.010 & 1.964 & 0.431 & 22 & 0.13 & 0.44 & 0.08 & 0.43 \\
\hline & Naphthalene & 1.959 & 0.015 & 2.002 & 0.370 & 19 & 0.15 & 0.38 & 0.07 & 0.37 \\
\hline \multirow{9}{*}{ Beillant } & Acetochlor & 1.965 & 0.031 & 2.779 & 0.866 & 31 & 0.41 & 1.02 & 0.61 & 0.81 \\
\hline & Alachlor & 2.046 & 0.023 & 2.025 & 0.474 & 23 & 0.22 & 0.53 & 0.27 & 0.45 \\
\hline & Atrazine & 1.986 & 0.011 & 2.228 & 1.021 & 46 & 0.43 & 1.04 & 0.22 & 1.01 \\
\hline & Desethylatrazine & 1.888 & 0.033 & 1.886 & 0.778 & 41 & 0.34 & 0.79 & 0.12 & 0.78 \\
\hline & Deisopropylatrazine & 2.037 & 0.031 & 1.989 & 0.733 & 37 & 0.32 & 0.75 & 0.16 & 0.73 \\
\hline & Diuron & 2.033 & 0.045 & 2.027 & 0.428 & 21 & 0.18 & 0.46 & 0.19 & 0.42 \\
\hline & Isoproturon & 2.019 & 0.019 & 1.976 & 0.713 & 36 & 0.30 & 0.72 & 0.13 & 0.71 \\
\hline & Metalochlor & 2.121 & 0.033 & 2.417 & 0.651 & 27 & 0.29 & 0.69 & 0.26 & 0.64 \\
\hline & Simazine & 2.225 & 0.026 & 2.728 & 1.128 & 41 & 0.45 & 1.17 & 0.37 & 1.11 \\
\hline \multirow{8}{*}{ Ternay } & Cadmium & 1.042 & 0.006 & 1.012 & 0.100 & 10 & 0.04 & 0.11 & 0.05 & 0.10 \\
\hline & Chromium & 1.040 & 0.010 & 1.022 & 0.229 & 22 & 0.09 & 0.23 & 0.06 & 0.23 \\
\hline & Cobalt & 1.005 & 0.040 & 1.024 & 0.077 & 7 & 0.03 & 0.08 & 0.03 & 0.07 \\
\hline & Copper & 1.100 & 0.022 & 1.125 & 0.111 & 10 & 0.05 & 0.13 & 0.07 & 0.11 \\
\hline & Manganese & 1.000 & 0.040 & 0.987 & 0.025 & 3 & 0.01 & ND & 0.06 & ND \\
\hline & Nickel & 1.040 & 0.012 & 0.947 & 0.152 & 16 & 0.06 & 0.16 & 0.06 & 0.15 \\
\hline & Lead & 1.050 & 0.008 & 0.978 & 0.073 & 7 & 0.03 & 0.08 & 0.03 & 0.07 \\
\hline & Zinc & 1.030 & 0.036 & 1.263 & 0.305 & 24 & 0.13 & 0.31 & 0.09 & 0.30 \\
\hline
\end{tabular}

${ }^{1}$ : quality controls used for the intercomparison exercises at Ternay (PAHs and metals) and at Beillant (pesticides).

ND: non determinated 
Table 3: Means and standard deviations of water concentrations (TWA concentrations) of PAHs and metals at Ternay, and pesticides at Beillant, with (i) all PSs, (ii) the most frequently used PSs (i.e., SPMD for PAHs, POCIS for pesticides and DGT for metals), and (iii) spot sampling (dissolved water fraction).

\begin{tabular}{|c|c|c|c|c|c|c|c|c|c|c|c|c|c|c|}
\hline Parameters & \begin{tabular}{|l} 
Population \\
mean
\end{tabular} & $\begin{array}{l}\text { Population } \\
\text { standard } \\
\text { deviation }\end{array}$ & $\begin{array}{l}\text { Robust } \\
\text { mean }\left(x^{*}\right)\end{array}$ & $\begin{array}{l}\text { Robust } \\
\text { reproductibility } \\
\text { standard deviation } \\
(S R)\end{array}$ & $\begin{array}{l}\text { Robust } \\
\text { reproductibility } \\
\text { relative standard } \\
\text { deviation }(S R)\end{array}$ & $n$ & $\begin{array}{l}\text { Robust mean } \\
(x *)\end{array}$ & $\begin{array}{l}\text { Robust } \\
\text { reproductibility } \\
\text { standard deviation } \\
\text { (SR) }\end{array}$ & $\begin{array}{l}\text { Robust } \\
\text { reproductibility } \\
\text { relative standard } \\
\text { deviation }(S R)\end{array}$ & $n$ & \begin{tabular}{|l} 
Population \\
mean
\end{tabular} & $\begin{array}{l}\text { Standard } \\
\text { deviation }\end{array}$ & $L O Q$ & $\begin{array}{l}n \\
\text { quantitated }\end{array}$ \\
\hline \multirow[t]{2}{*}{ Units } & \multicolumn{4}{|c|}{$n g / \mathcal{L}$ for organics, $\mu \mathrm{g} / \mathcal{L}$ for metals } & \multicolumn{2}{|l|}{$\%$} & \multicolumn{4}{|c|}{$n g / L$ for organics, $\mu g / L$ for metals } & \multicolumn{4}{|c|}{$n g / \mathcal{L}$ for organics, $\mu \mathrm{g} / \mathcal{L}$ for metals } \\
\hline & \multicolumn{6}{|c|}{ All passive sampless } & \multicolumn{4}{|c|}{ SPMD only } & \multicolumn{4}{|c|}{ Spot sampling } \\
\hline benz(a)anthracene & 0.812 & 0.805 & 0.806 & 0.758 & 94 & 21 & 1.001 & 0.892 & 89 & 11 & 0.4 & $\mathrm{~N} / \mathrm{A}$ & 0.4 & 1 \\
\hline benzo(a)pyrene & 0.160 & 0.157 & 0.144 & 0.134 & 93 & 19 & 0.239 & 0.218 & 91 & 9 & $<\mathrm{LOQ}$ & N/A & 0.4 & 0 \\
\hline benzo(b)fluoranthene & 0.291 & 0.278 & 0.248 & 0.190 & 77 & 20 & 0.424 & 0.375 & 88 & 11 & $<\mathrm{LOQ}$ & N/A & 0.4 & 0 \\
\hline benzo(k)fluoranthene & 0.191 & 0.277 & 0.127 & 0.115 & 91 & 19 & 0.177 & 0.142 & 80 & 9 & $<L O Q$ & N/A & 0.4 & 0 \\
\hline indeno(1,2,3-cd)pyrene & 0.032 & 0.039 & 0.027 & 0.023 & 85 & 14 & 0.055 & 0.038 & 69 & 7 & 1.3 & 0.3 & 0.4 & 2 \\
\hline phenanthrene & 7.924 & 9.436 & 5.757 & 4.612 & 80 & 22 & 8.007 & 5.001 & 62 & 11 & 2.9 & 0.2 & 2 & 3 \\
\hline acenaphthene & 8.295 & 8.033 & 6.606 & 5.580 & 84 & 18 & 10.245 & 9.149 & 89 & 9 & 4.8 & 4.5 & 0.4 & 6 \\
\hline acenaphthylene & 8.849 & 24.661 & 1.603 & 2.085 & 130 & 14 & 0.322 & 0.199 & 62 & 6 & 6.3 & N/A & 5 & 1 \\
\hline anthracene & 1.883 & 1.573 & 1.594 & 1.287 & 81 & 21 & 1.598 & 1.130 & 71 & 11 & 1.2 & N/A & 0.4 & 1 \\
\hline benzo(gh, $\mathrm{h})$ perylene & 0.083 & 0.180 & 0.051 & 0.051 & 100 & 15 & 0.220 & 0.278 & 126 & 6 & $<\mathrm{LOQ}$ & N/A & 0.4 & 0 \\
\hline chrysene & 1.079 & 0.976 & 1.069 & 0.940 & 88 & 21 & 1.369 & 1.266 & 93 & 11 & 0.4 & N/A & 0.4 & 1 \\
\hline fluoranthene & 6.758 & 8.349 & 4.839 & 3.792 & 78 & 22 & 9.260 & 10.192 & 110 & 11 & 6.5 & 1.4 & 0.4 & 6 \\
\hline fluorene & 5.373 & 5.207 & 4.913 & 4.590 & 93 & 21 & 7.270 & 6.093 & 84 & 10 & 2.3 & 2.6 & 0.4 & 4 \\
\hline naphthalene & 7.535 & 12.230 & 9.495 & 9.847 & 104 & 8 & 10.133 & 8.923 & 88 & 4 & 3 & 1.7 & 0.4 & 4 \\
\hline \multirow[t]{2}{*}{ pyrene } & 5.213 & 4.548 & 4.797 & 3.041 & 63 & 22 & 5.392 & 4.505 & 84 & 11 & 1.5 & 1 & 0.4 & 6 \\
\hline & \multicolumn{6}{|c|}{ All passive sampless } & \multicolumn{4}{|c|}{ POCIS only } & \multicolumn{4}{|c|}{ Spot sampling } \\
\hline acetochlor & 4.064 & 3.423 & 3.843 & 3.932 & 102 & 5 & 3.018 & 1.738 & 58 & 3 & $\Leftrightarrow \mathrm{LOQ}$ & N/A & 10 & 0 \\
\hline alachlor & 2.036 & 1.262 & 1.858 & 1.558 & 84 & 2 & 1.858 & 1.558 & 84 & 2 & $\angle L O Q$ & N/A & 10 & 0 \\
\hline atrazine & 18.571 & 42.858 & 6.735 & 7.455 & 111 & 12 & 3.873 & 2.530 & 65 & 9 & $<\mathrm{LOQ}$ & N/A & 20 & 0 \\
\hline desethylatrazine & 36.639 & 36.439 & 35.890 & 39.977 & 111 & 7 & 35.890 & 39.977 & 111 & 7 & 49.2 & 3.5 & 10 & 5 \\
\hline deisopropylatrazine & 9.148 & 7.733 & 7.520 & 4.525 & 60 & 7 & 7.520 & 4.525 & 60 & 7 & 13.3 & 0.5 & 10 & 5 \\
\hline diuron & 2.028 & 0.601 & 2.103 & 0.763 & 36 & 6 & 1.983 & 0.771 & 39 & 5 & $<\mathrm{LOQ}$ & N/A & 20 & 0 \\
\hline isoproturon & 0.413 & 0.121 & 0.413 & 0.148 & 36 & 3 & 0.413 & 0.148 & 36 & 3 & $\Leftrightarrow L O Q$ & $\mathrm{~N} / \mathrm{A}$ & 10 & 0 \\
\hline metalochlor & 19.014 & 29.257 & 10.647 & 7.023 & 66 & 9 & 10.085 & 5.207 & 52 & 7 & $18.3^{\circ}$ & 5.0 & 10 & 5 \\
\hline \multirow[t]{2}{*}{ simazine } & 21.860 & 3.936 & 6.613 & 5.753 & 87 & 8 & 6.044 & 4.525 & 75 & 6 & $\approx \mathrm{LOQ}$ & N/A & 20 & 0 \\
\hline & \multicolumn{6}{|c|}{ All passive sampless } & \multicolumn{4}{|c|}{ DGT only } & \multicolumn{4}{|c|}{ Spot sampling } \\
\hline cadruium & 0.0107 & 0.0151 & 0.0053 & 0.0031 & 59 & 12 & 0.0048 & 0.0027 & 57 & 11 & 0.013 & 0.002 & 0.01 & 3 \\
\hline chromium & 0.0773 & 0.0599 & 0.0756 & 0.0705 & 93 & 11 & 0.0756 & 0.0705 & 93 & 11 & 0.162 & 0.012 & 0.05 & 3 \\
\hline cobalt & 0.0332 & 0.0177 & 0.0292 & 0.0111 & 38 & 9 & 0.0292 & 0.0111 & 38 & 9 & 0.158 & 0.007 & 0.05 & 3 \\
\hline copper & 0.4168 & 0.2488 & 0.3672 & 0.1533 & 42 & 13 & 0.3708 & 0.1696 & 46 & 12 & 0.994 & 0.045 & 0.05 & 3 \\
\hline manganese & 4.2124 & 2.7857 & 3.4760 & 0.9902 & 28 & 11 & 3.4760 & 0.9902 & 28 & 11 & 3.611 & 1.247 & 0.10 & 3 \\
\hline nickel & 0.4231 & 0.1965 & 0.3920 & 0.1390 & 35 & 13 & 0.3959 & 0.1536 & 39 & 12 & 0.733 & 0.118 & 0.05 & 3 \\
\hline lead & 0.0755 & 0.0843 & 0.0630 & 0.0705 & 112 & 12 & 0.0491 & 0.0513 & 104 & 11 & 0.367 & 0.630 & 0.05 & 3 \\
\hline zinc & 1.6674 & 1.5392 & 1.4050 & 1.1034 & 79 & 10 & 1.1958 & 0.8407 & 70 & 9 & 1.847 & 0.063 & 0.50 & 3 \\
\hline
\end{tabular}


Table 4: Comparison of interlaboratory uncertainties on pesticide concentrations between this in situ exercise on field (at Beillant) using PSs and a proficiency testing [15] in spot natural samples.

\begin{tabular}{|c|c|c|c|c|c|c|}
\hline \multirow[b]{2}{*}{ Parameters } & \multicolumn{3}{|c|}{ Passive sampler data } & \multicolumn{3}{|c|}{$\begin{array}{c}\text { SWIFT-WFD Proficiency Testing Exercise } \\
\text { (natural water) }\end{array}$} \\
\hline & $\begin{array}{l}\text { Robust mean } \\
x^{*} \pm 1 S D(n g / L)\end{array}$ & $n$ & $\begin{array}{l}\text { Robust reproducibility } \\
\qquad(\% R S D)\end{array}$ & $\begin{array}{l}\text { Robust mean } \\
x^{*} \pm 1 S D(n g / L)\end{array}$ & $n$ & $\begin{array}{c}\text { Robust reproducibility } \\
(\% R S D)\end{array}$ \\
\hline alachlor & $1.8 \pm 1.6$ & 2 & 84 & $144 \pm 52$ & 16 & 36 \\
\hline atrazine & $6.7 \pm 7.5$ & 12 & 111 & $131 \pm 32$ & 14 & 24 \\
\hline diuron & $2.1 \pm 0.8$ & 6 & 36 & $152 \pm 72$ & 11 & 47 \\
\hline isoproturon & $0.4 \pm 0.1$ & 3 & 36 & $133 \pm 44$ & 11 & 33 \\
\hline simazine & $6.6 \pm 5.7$ & 8 & 87 & $136 \pm 33$ & 13 & 24 \\
\hline
\end{tabular}


Figures
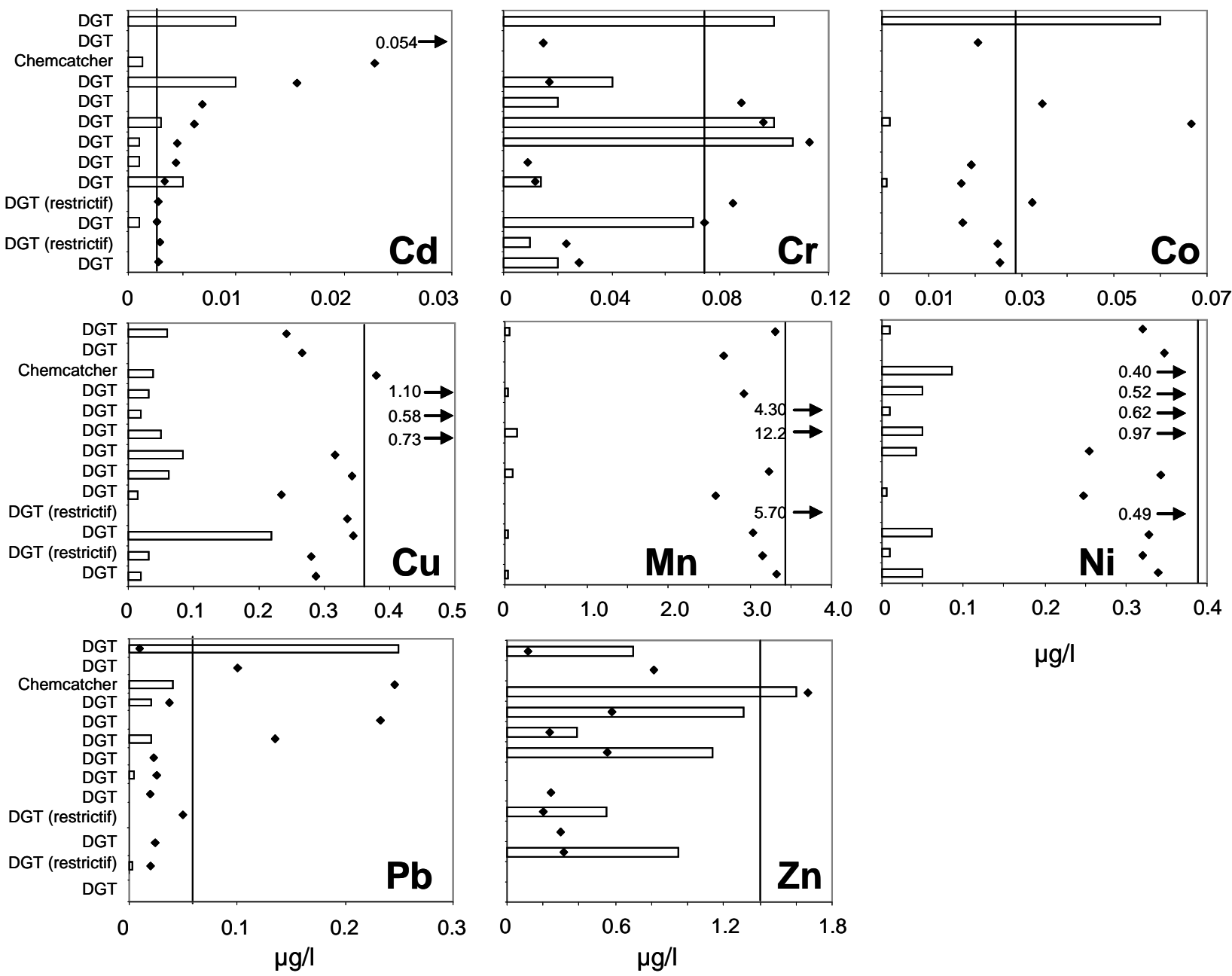

$\mu g / l$

Figure 1: Comparison of robust mean TWA concentrations (solid line), TWA concentrations (black diamonds) and field blank concentrations (histograms) for each laboratory, for metals $(\mu \mathrm{g} / \mathrm{L})$ at Ternay site. 

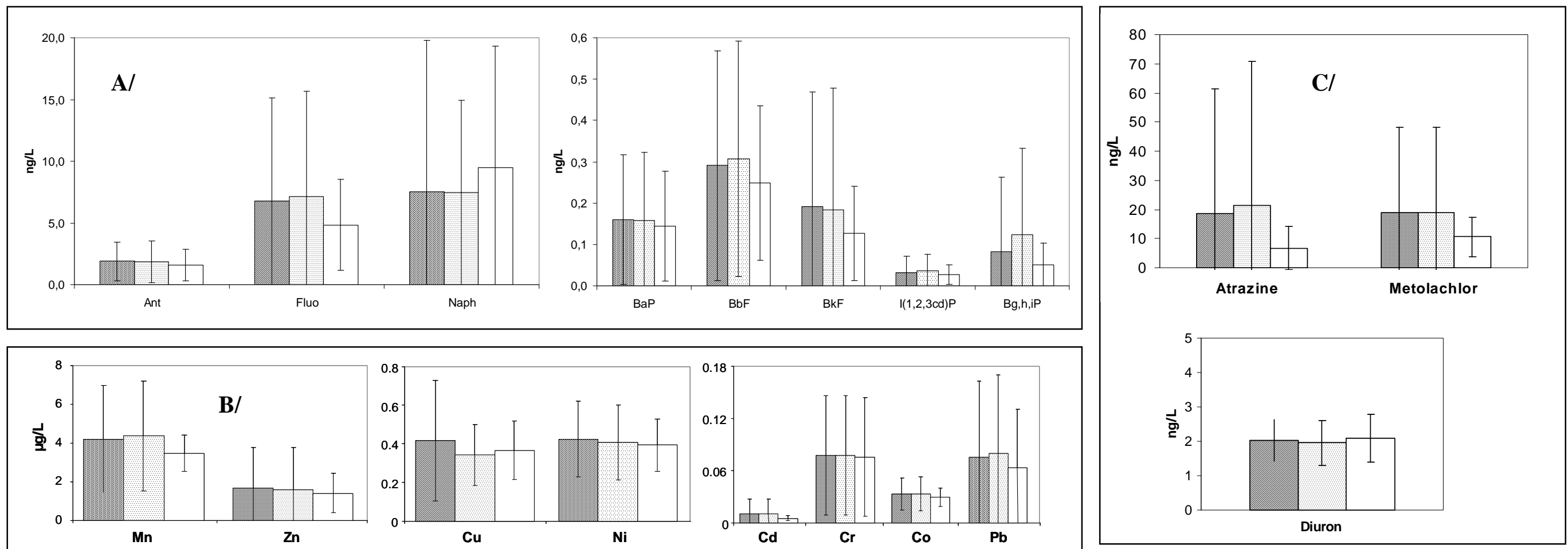

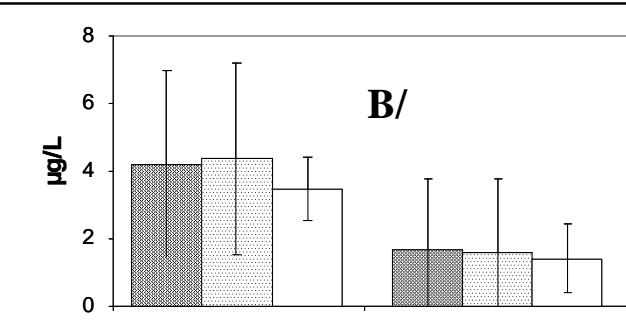

Mn

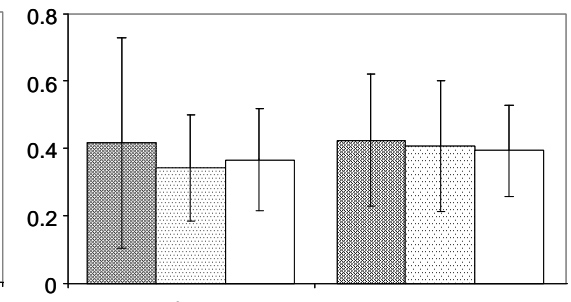

$\mathrm{Cu}$

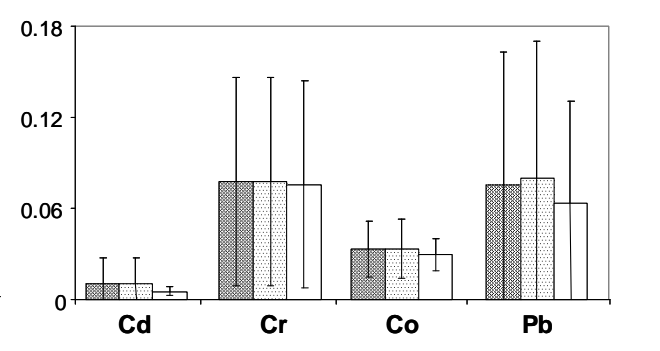

Means and standard deviations (all participants)

Means and standard deviations (without QC outliers)

$\square$ Robust statistic (all participants)

Figure 2: Classical or robust means and reproducibility standard deviations of TWA concentrations of A/ PAHs and B/ metals at Ternay, and C/ selected pesticides at Beillant. 


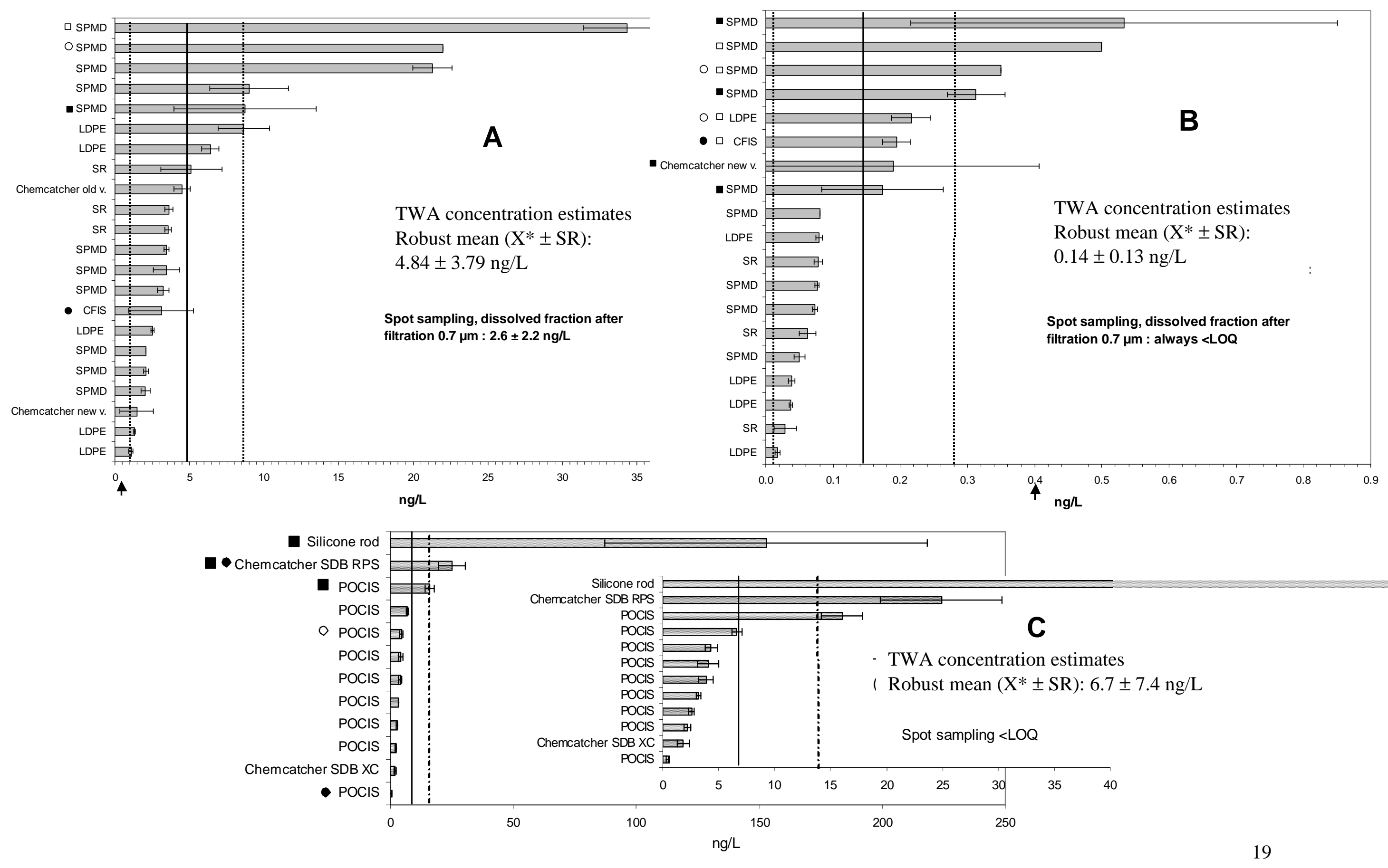


Silicone rod
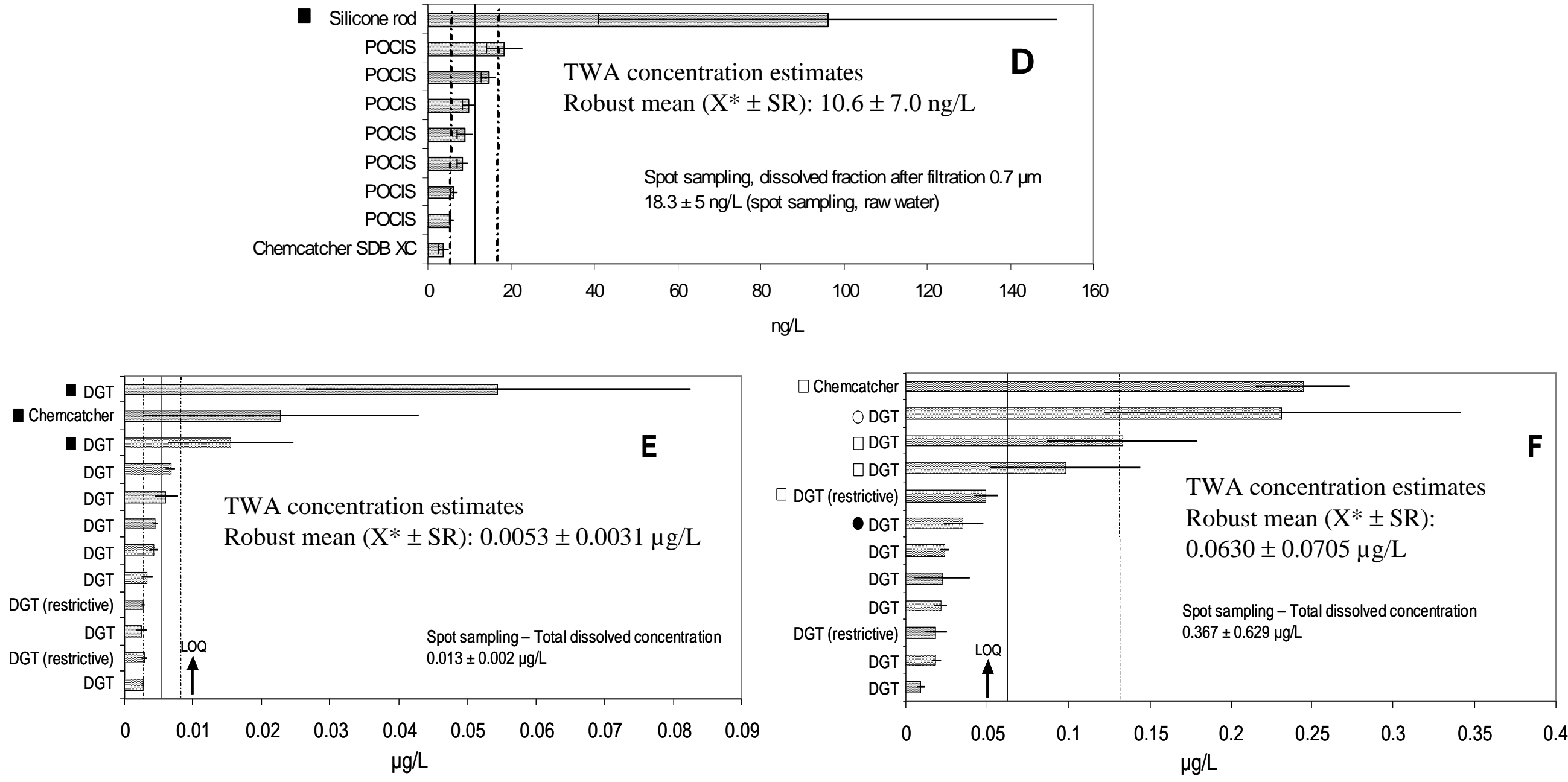
- - Robust mean
CQ Dispersion (Cochran)
$--S_{R}$
$\bigcirc$ Mean (Grubbs)
Data Dispersion (Cochran)
$\square$ Mean (Grubbs)

Figure 3: Comparison of TWA concentrations for each participant (histograms) with robust mean TWA concentration for all participants (vertical line), for 2 PAHs (A/ Fluoranthene, B/ Benzo(a)pyrene) and 2 metals $(\mathrm{E} / \mathrm{Cd}, \mathrm{F} / \mathrm{Pb})$ at Ternay and 2 pesticides $(\mathrm{C} / \mathrm{Atrazine}$, D/ Metolachlor) at Beillant. Outliers identified by Cochran tests on QC data $\bullet$, outliers identified by Grubbs tests on QC data $\bigcirc$, outliers identified by Cochran tests on PS data $\mathbf{\square}$, Outliers identified by Grubbs tests on PS data $\square$. X*: robust mean, SR: robust reproducibility. 


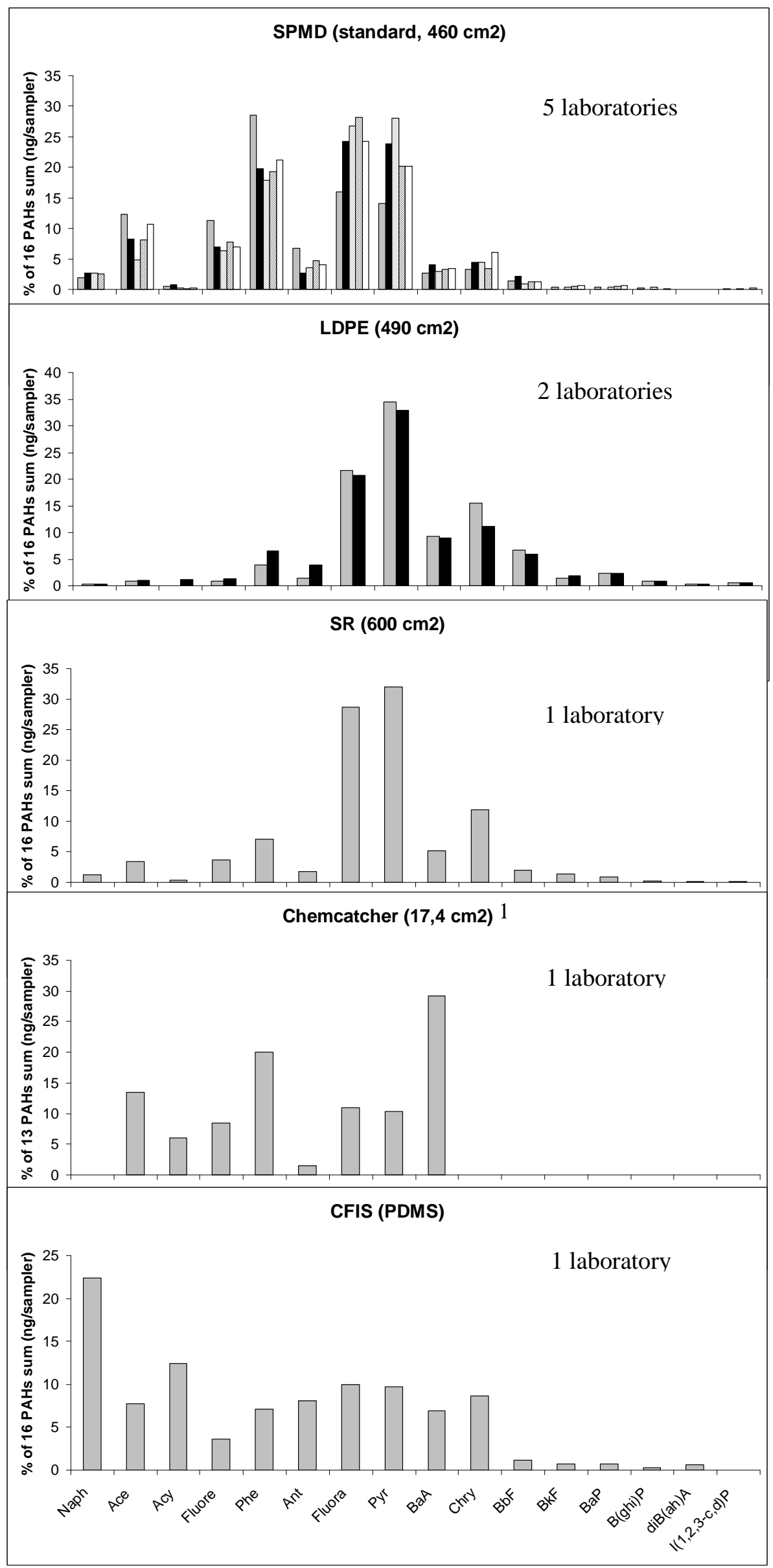




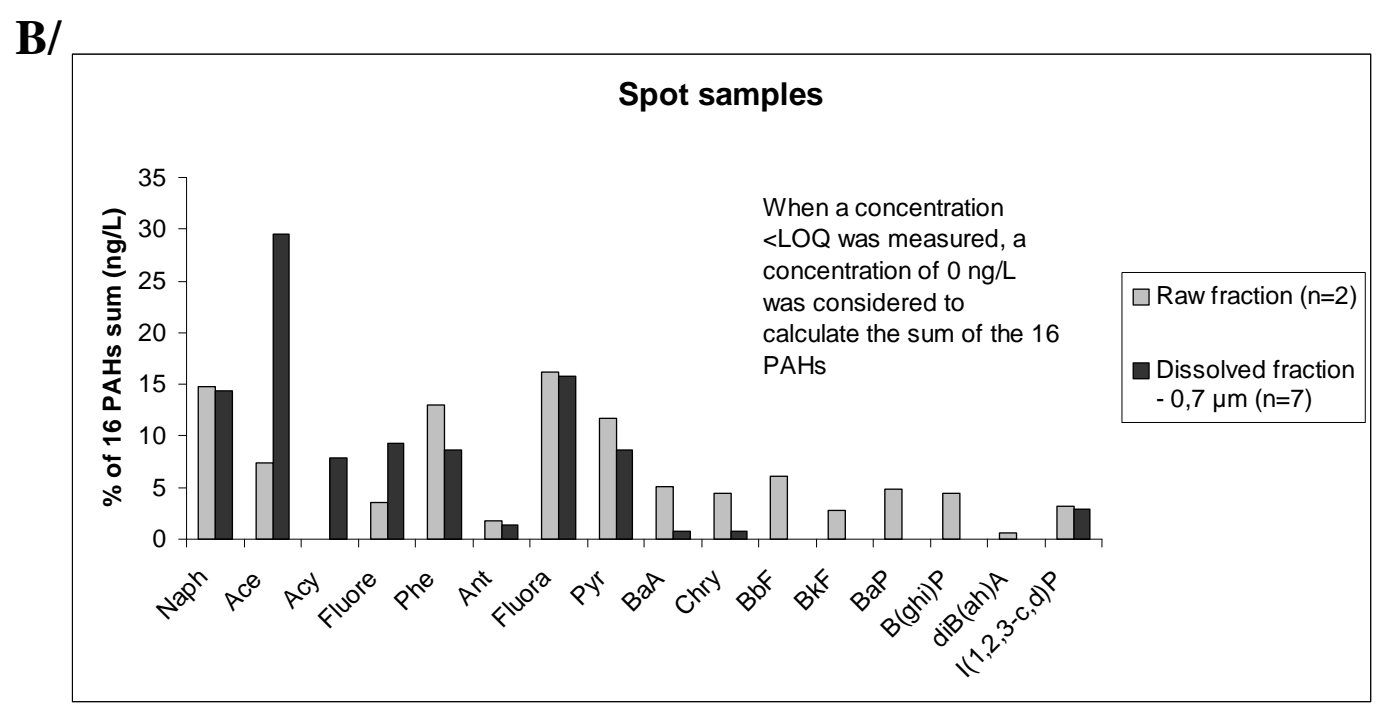

Figure 4: Comparison of the 16 PAHs fingerprints at Ternay for A/ 5 PSs and B/ spot sampling of bulk and dissolved water fractions.

1: For Chemcatcher, 3 PAHs were not measured, i.e. Naph, B(ghi)P, I(1,2,3-cd)P.

Naph: Naphthalene, Ace: Acenaphthene, Acy: Acenaphthylene, Fluore: Fluorene, Phe: Phenanthrene, Ant: Anthracene, Fluora: Fluoranthene, Pyr: Pyrene, BaA: Benz(a)Anthracene, Chry: Chrysene, Bbf: Benzo(b)Fluoranthene, BkF: Benzo(k)Fluoranthene, BaP: Benzo(a)Pyrene, B(ghi)P: Benzo(g,h,i)Perylene, diB(ah)A: DiBenz(a,h)Anthracene, I(1,2,3cd)P: Indeno(1,2,3-cd)Pyrene.

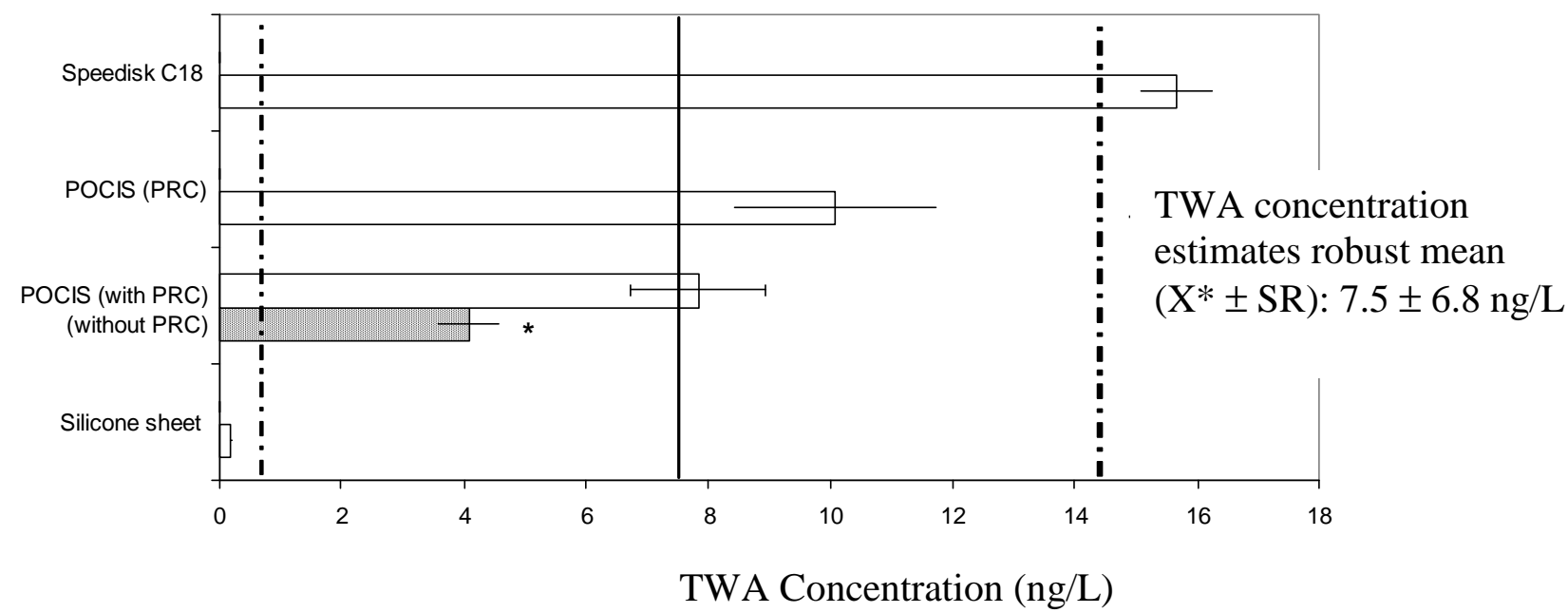

Figure 5: Comparison of TWA concentrations (ng/L) for 4 participants (histograms) with robust mean TWA concentration for all participants (vertical line) for diuron at Thau; and comparison of POCIS data with or without the use of DIA-d5 as PRC. A star is indicating a significant difference between POCIS TWA concentrations (Mann-Withney test, $\mathrm{p}=0.05$ ). $\mathrm{X}^{*}$ : robust mean, $\mathrm{SR}$ : robust reproducibility. 
Supplementary Material: Characteristics of the 3 exposure sites measured on spot samples.

Trials were conducted on two rivers, Charente River, Beillant, France (from 27th of May to 10th of June, pesticides) and Rhône River, Ternay, France (from 17th of June to 8th of July, metals and PAH); and at one marine site, Thau Lagoon, Hérault, France (from 27th of April to 18th of May, metals, pesticides and PAHs).

Six central laboratories were in charge of water analysis: BRGM of Orléans (HAP), Irstea/Cemagref of Bordeaux (pesticides, physico-chemical parameters in Beillant site), Irstea/Cemagref of Lyon (metals, physico-chemical parameters in Ternay site), EPOC-LPTC of Bordeaux (pesticides and PAHs in Thau site), IFREMER of Sète (physico-chemical parameters in Thau site), IFREMER of Nantes (RBE/BE/LBCM) (metals in Thau site).

\begin{tabular}{|c|c|c|c|c|c|c|c|c|c|c|c|c|}
\hline & & & & & TERI & JAY & & & & & & \\
\hline Par & ameter & Unit & $17 / 06 / 2010$ & $21 / 06 / 2010$ & $24 / 06 / 2010$ & $28 / 06 / 2010$ & $01 / 07 / 2010$ & 05/07/2010 & $08 / 07 / 2010$ & Average & Std Dev & $\mathrm{n}$ \\
\hline Ten & nperature & ${ }^{\circ}$ & 17.3 & 16.3 & 17.3 & 20.9 & 21.3 & 23.0 & 22.5 & 19.8 & 2.7 & 7 \\
\hline Vel & ocity & $\mathrm{m} / \mathrm{s}$ & 0.148 & 0.316 & 0.175 & 0.175 & not measured & 0.170 & 0.317 & 0.217 & 0.078 & 6 \\
\hline $\mathrm{pH}$ & & & 7.8 & 8 & 7.9 & 7.8 & 7 & 6.9 & 7.9 & 7.6 & 0.5 & 7 \\
\hline Cor & nductimetry & $\mu \mathrm{Sm} / \mathrm{cm}$ & 370 & 400 & 405 & 430 & 375 & 400 & 345 & 389 & 28 & 7 \\
\hline Tot & al suspended matter & $\mathrm{mg} / \mathrm{L}$ & 19 & 39 & 13 & 5.8 & 9.1 & 3.5 & 8.4 & 14.0 & 12.1 & 7 \\
\hline $\mathrm{TO}$ & & $\mathrm{mg} / \mathrm{L}$ & 2.15 & 2.8 & 2.55 & 2.75 & 2.1 & 2.55 & 2.4 & 2.47 & 0.27 & 7 \\
\hline $\mathrm{DO}$ & & $\mathrm{mg} / \mathrm{L}$ & 2.15 & 2.65 & 2.5 & 2.8 & 2.05 & 2.45 & 2.2 & 2.4 & 0.3 & 7 \\
\hline $\mathrm{NH}$ & & $\mathrm{mg} / \mathrm{L}$ & 0.29 & 0.13 & 0.14 & 0.2 & 0.22 & 0.26 & 0.19 & 0.20 & 0.06 & 7 \\
\hline $\mathrm{NO}$ & & $\mathrm{mg} / \mathrm{L}$ & 0.11 & 0.09 & 0.07 & 0.1 & 0.08 & 0.07 & 0.06 & 0.08 & 0.02 & 7 \\
\hline $\mathrm{NO}$ & & $\mathrm{mg} / \mathrm{L}$ & 4.5 & 6.4 & 6.5 & 7.6 & 4.8 & 6.1 & 4.2 & 5.7 & 1.3 & 7 \\
\hline $\mathrm{PO}$ & & $\mathrm{mg} / \mathrm{L}$ & 0.19 & 0.25 & 0.17 & 0.25 & 0.14 & 0.15 & 0.17 & 0.19 & 0.04 & 7 \\
\hline $\mathrm{HC}$ & $\mathrm{O3}$ & $\mathrm{mg} / \mathrm{L}$ & 145 & 165 & 170 & 180 & 160 & 165 & 140 & 161 & 14 & 7 \\
\hline $\mathrm{Cl}$ & & $\mathrm{mg} / \mathrm{L}$ & 19 & 19 & 21 & 20 & 15 & 17 & 13 & 18 & 3 & 7 \\
\hline $\mathrm{SO}$ & & $\mathrm{mg} / \mathrm{L}$ & 37 & 32 & 35 & 35 & 35 & 37 & 39 & 36 & 2 & 7 \\
\hline $\mathrm{Ca}$ & & $\mathrm{mg} / \mathrm{L}$ & 57 & 58 & 63 & 67 & 58 & 62 & 52 & 60 & 5 & 7 \\
\hline $\mathrm{Mg}$ & & $\mathrm{mg} / \mathrm{L}$ & 5.5 & 5.4 & 5.8 & 5.6 & 5.7 & 5.5 & 5.4 & 5.6 & 0.2 & 7 \\
\hline $\mathrm{Na}$ & & $\mathrm{mg} / \mathrm{L}$ & 11 & 14.5 & 12 & 13 & 9 & 12.5 & 8.5 & 11.5 & 2.2 & 7 \\
\hline $\mathrm{K}$ & & $\mathrm{mg} / \mathrm{L}$ & 1.8 & 3.7 & 2 & 2.1 & 1.4 & 1.9 & 1.4 & 2.0 & 0.8 & 7 \\
\hline & Acenaphthylene & ng/L & $\angle \mathrm{LOQ}$ & 6.3 & $\angle \mathrm{LOQ}$ & Contamination & $\angle \mathrm{LOQ}$ & $<\mathrm{LOQ}$ & $\angle \mathrm{LOQ}$ & 6.3 & & $\overline{6}$ \\
\hline & Acenaphthene & $\mathrm{ng} / \mathrm{L}$ & 0.5 & 2.2 & $<\mathrm{LOQ}$ & 8.4 & 5.4 & 11.6 & 0.5 & 4.8 & 4.5 & 7 \\
\hline & Anthracene & $\mathrm{ng} / \mathrm{L}$ & $<\mathrm{LOQ}$ & $<\mathrm{LOQ}$ & $<\mathrm{LOQ}$ & $<\mathrm{LOQ}$ & $<\mathrm{LOQ}$ & 1.2 & $<\mathrm{LOQ}$ & 1.2 & & 7 \\
\hline & Benz(a)anthracene & $\mathrm{ng} / \mathrm{L}$ & $<\mathrm{LOQ}$ & $<\mathrm{LOQ}$ & $<\mathrm{LOQ}$ & $<\mathrm{LOQ}$ & $<\mathrm{LOQ}$ & 0.4 & $<\mathrm{LOQ}$ & 0.4 & & 7 \\
\hline & Benzo(a)pyrene & $\mathrm{ng} / \mathrm{L}$ & $<\mathrm{LOQ}$ & $<\mathrm{LOQ}$ & $<\mathrm{LOQ}$ & $<\mathrm{LOQ}$ & $<\mathrm{LOQ}$ & $<\mathrm{LOQ}$ & $<\mathrm{LOQ}$ & & & 7 \\
\hline 든 & Benzo(b)fluoranthene & $\mathrm{ng} / \mathrm{L}$ & $<\mathrm{LOQ}$ & $<\mathrm{LOQ}$ & $<\mathrm{LOQ}$ & $<L O Q$ & $<\mathrm{LOQ}$ & $<\mathrm{LOQ}$ & $<\mathrm{LOQ}$ & & & 7 \\
\hline 苞 & Benzo(k)fluoranthene & $\mathrm{ng} / \mathrm{L}$ & $<\mathrm{LOQ}$ & $<\mathrm{LOQ}$ & $<\mathrm{LOQ}$ & $<L O Q$ & $<\mathrm{LOQ}$ & $<\mathrm{LOQ}$ & $<\mathrm{LOQ}$ & & & 7 \\
\hline$\stackrel{0}{=}$ & Benzo(ghi)perylene & $\mathrm{ng} / \mathrm{L}$ & $<\mathrm{LOQ}$ & $<\mathrm{LOQ}$ & $<\mathrm{LOQ}$ & $<\mathrm{LOQ}$ & $<\mathrm{LOQ}$ & $<\mathrm{LOQ}$ & $<\mathrm{LOQ}$ & & & 7 \\
\hline D & \begin{tabular}{|l} 
Indeno( $1,2,3-c d) p y r e n e$ \\
\end{tabular} & $\mathrm{ng} / \mathrm{L}$ & $<\mathrm{LOQ}$ & $<\mathrm{LOQ}$ & $<\mathrm{LOQ}$ & $<\mathrm{LOQ}$ & 1.1 & 1.5 & $<\mathrm{LOQ}$ & 1.3 & 0.3 & 7 \\
\hline оे & Chrysene & $\mathrm{ng} / \mathrm{L}$ & $<\mathrm{LOQ}$ & $<\mathrm{LOQ}$ & $<\mathrm{LOQ}$ & $<\mathrm{LOQ}$ & $<\mathrm{LOQ}$ & 0.4 & $<\mathrm{LOQ}$ & 0.4 & & 7 \\
\hline 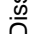 & Dibenz(a,h)anthracene & $\mathrm{ng} / \mathrm{L}$ & $<\mathrm{LOQ}$ & $<\mathrm{LOQ}$ & $<\mathrm{LOQ}$ & $<\mathrm{LOQ}$ & $<\mathrm{LOQ}$ & $<\mathrm{LOQ}$ & $<\mathrm{LOQ}$ & & & 7 \\
\hline & \begin{tabular}{|l|} 
Fluoranthene \\
\end{tabular} & $\mathrm{ng} / \mathrm{L}$ & 0.5 & 1.1 & $<\mathrm{LOQ}$ & 2.9 & 3.3 & 6.5 & 1.4 & 2.6 & 2.2 & 7 \\
\hline & \begin{tabular}{|l|} 
Fluorene \\
\end{tabular} & $\mathrm{ng} / \mathrm{L}$ & $<\mathrm{LOQ}$ & 0.8 & $<\mathrm{LOQ}$ & 1.5 & $<\mathrm{LOQ}$ & 6.2 & 0.6 & 2.3 & 2.6 & 7 \\
\hline & Naphthalene & $\mathrm{ng} / \mathrm{L}$ & $<\mathrm{LOQ}$ & 1.9 & 1.6 & 3.3 & Contamination & 5.3 & $<\mathrm{LOQ}$ & 3.0 & 1.7 & 6 \\
\hline & \begin{tabular}{|l} 
Phenanthrene \\
\end{tabular} & $\mathrm{ng} / \mathrm{L}$ & $<\mathrm{LOQ}$ & $<\mathrm{LOQ}$ & $<\mathrm{LOQ}$ & 2.8 & 2.7 & 3.1 & $<\mathrm{LOQ}$ & 2.9 & 0.2 & 7 \\
\hline & Pyrene & $\mathrm{ng} / \mathrm{L}$ & 0.4 & 1 & $<\mathrm{LOQ}$ & 1.6 & 1.9 & 3.1 & 0.7 & 1.5 & 1.0 & 7 \\
\hline$\overline{C \text { Chr }}$ & romium & $\mu \mathrm{g} / \mathrm{L}$ & 0.170 & 0.149 & 0.168 & & & & & 0.162 & 0.012 & 3 \\
\hline Mar & ngenese & $\mu \mathrm{g} / \mathrm{L}$ & 3.93 & 2.23 & 4.67 & & & & & 3.61 & 1.25 & 3 \\
\hline $\mathrm{Cok}$ & oalt & $\mu \mathrm{g} / \mathrm{L}$ & 0.159 & 0.151 & 0.166 & & & & & 0.158 & 0.007 & 3 \\
\hline $\mathrm{Nic}$ & $\mathrm{kel}$ & $\mu \mathrm{g} / \mathrm{L}$ & 0.650 & 0.680 & 0.869 & & & & & 0.733 & 0.118 & 3 \\
\hline Cop & oper & $\mu \mathrm{g} / \mathrm{L}$ & 0.95 & 0.99 & 1.04 & & & & & 0.99 & 0.05 & 3 \\
\hline Zinc & & $\mu \mathrm{g} / \mathrm{L}$ & 2.42 & 0.78 & 2.33 & & & & & 1.85 & 0.92 & 3 \\
\hline $\mathrm{Cac}$ & dmium & $\mu \mathrm{g} / \mathrm{L}$ & 0.015 & 0.012 & 0.012 & & & & & 0.013 & 0.002 & 3 \\
\hline Lea & & $\mu \mathrm{g} / \mathrm{L}$ & 0.966 & 0.076 & 0.060 & & & & & 0.521 & 0.630 & 3 \\
\hline
\end{tabular}


BEILLANT

\begin{tabular}{|c|c|c|c|c|c|c|c|c|c|c|}
\hline & & & & & EILLANT & & & & & \\
\hline Param & & Unit & $27 / 05 / 2010$ & $31 / 05 / 2010$ & $04 / 06 / 2010$ & $07 / 06 / 2010$ & $10 / 06 / 2010$ & Average & Std Dev & $\mathrm{n}$ \\
\hline Temp & ature & ${ }^{\circ} \mathrm{C}$ & & Measured & ntinuously (e & ery hours) & & 19.4 & 1.1 & 335 \\
\hline Veloci & & $\mathrm{m} / \mathrm{s}$ & 0.01 & $\mathrm{~N} / \mathrm{A}$ & $\mathrm{N} / \mathrm{A}$ & $\mathrm{N} / \mathrm{A}$ & 0.02 & $0.01-0.02$ & $\mathrm{~N} / \mathrm{A}$ & 2 \\
\hline $\mathrm{pH}$ & & & 8 & 8 & 8 & 8.1 & 7.9 & 8.0 & 0.1 & 5 \\
\hline Condu & timetry & $\mu \mathrm{Sm} / \mathrm{cm}$ & 524 & 534 & 551 & 546 & 544 & 539.8 & 10.8 & 5 \\
\hline Tota s & spended matter & $\mathrm{mg} / \mathrm{L}$ & 6.4 & 7.6 & 6 & 7.2 & 7.6 & 7.0 & 0.7 & 5 \\
\hline TOC & & $\mathrm{mg} / \mathrm{L}$ & 3.1 & 3.1 & 3.6 & 3.3 & 3.4 & 3.3 & 0.2 & 5 \\
\hline DOC & & $\mathrm{mg} / \mathrm{L}$ & 3.2 & 3 & 4.2 & 5.1 & 3.4 & 3.8 & 0.9 & 5 \\
\hline$\overline{\mathrm{NH} 4}$ & & $\mathrm{mg} / \mathrm{L}$ & 0.1 & 0.1 & 0.1 & 0.1 & 0.1 & 0.1 & 0.0 & 5 \\
\hline NO2 & & $\mathrm{mg} / \mathrm{L}$ & 0 & 0.1 & 0.1 & 0.1 & 0.1 & 0.1 & 0.0 & 5 \\
\hline NO3 & & $\mathrm{mg} / \mathrm{L}$ & 24.7 & 24.1 & 24.5 & 25.3 & 23.6 & 24.4 & 0.6 & 5 \\
\hline NKJ & & $\mathrm{mg} / \mathrm{L}$ & 1.1 & 0.6 & 0.8 & 0.9 & 0.7 & 0.8 & 0.2 & 5 \\
\hline PO4 & & $\mathrm{mg} / \mathrm{L}$ & 0.2 & 0.2 & 0.1 & 0.1 & 0.1 & 0.1 & 0.1 & 5 \\
\hline $\mathrm{Cl}$ & & $\mathrm{mg} / \mathrm{L}$ & 20.9 & 20.3 & 20.1 & 19.7 & 20.1 & 20.2 & 0.4 & 5 \\
\hline $\mathrm{Ca}$ & & $\mathrm{mg} / \mathrm{L}$ & 94.5 & 94.3 & 96.4 & 95.7 & 95.9 & 95.4 & 0.9 & 5 \\
\hline $\mathrm{Mg}$ & & $\mathrm{mg} / \mathrm{L}$ & 7.9 & 6.7 & 7.1 & 6.9 & 6.5 & 7.0 & 0.5 & 5 \\
\hline & Acetochlor & $\mathrm{ng} / \mathrm{L}$ & $<\mathrm{LD}$ & $<\mathrm{LOQ}$ & $<\mathrm{LLD}$ & $<\mathrm{LOQ}$ & $<\mathrm{LD}$ & $\mathrm{N} / \mathrm{A}$ & $\mathrm{N} / \mathrm{A}$ & 0 \\
\hline$\subsetneq$ & Alachlor & $\mathrm{ng} / \mathrm{L}$ & $<\mathrm{LD}$ & $<L D$ & $<\mathrm{LD}$ & $<\mathrm{LD}$ & $<L D$ & $\mathrm{~N} / \mathrm{A}$ & $\mathrm{N} / \mathrm{A}$ & 0 \\
\hline 은 & Atrazine & $\mathrm{ng} / \mathrm{L}$ & $<\mathrm{LOQ}$ & $<\mathrm{LOQ}$ & $<L O Q$ & $<\mathrm{LOQ}$ & $<L O Q$ & $\mathrm{~N} / \mathrm{A}$ & $\mathrm{N} / \mathrm{A}$ & 0 \\
\hline$\stackrel{\pi}{=}$ & Desethylatrazine & $\mathrm{ng} / \mathrm{L}$ & 53.2 & 44.0 & 48.8 & 51.4 & 48.6 & 49.2 & 3.5 & 5 \\
\hline ర్ర & Deisopropylatrazine & $\mathrm{ng} / \mathrm{L}$ & 12.8 & 13.9 & 13.1 & 13.8 & 13.2 & 13.3 & 0.5 & 5 \\
\hline$\frac{\$}{0}$ & Diuron & ng/L & $<\mathrm{LD}$ & $<\mathrm{LD}$ & $<\mathrm{LD}$ & $<L O Q$ & $<L O Q$ & $\mathrm{~N} / \mathrm{A}$ & $\mathrm{N} / \mathrm{A}$ & 0 \\
\hline$\underline{\underline{D}}$ & Isoproturon & $\mathrm{ng} / \mathrm{L}$ & $<\mathrm{LOQ}$ & $<\mathrm{LOQ}$ & $<L O Q$ & $<\mathrm{LOQ}$ & $<L O Q$ & $\mathrm{~N} / \mathrm{A}$ & $\mathrm{N} / \mathrm{A}$ & 0 \\
\hline$\overline{0}$ & Metalochlor & $\mathrm{ng} / \mathrm{L}$ & 13.7 & 16.0 & 22.9 & 14.4 & 24.6 & 18.3 & 5.0 & 5 \\
\hline & Simazine & ng/L & $<\mathrm{LOQ}$ & $<\mathrm{LOQ}$ & $<\mathrm{LOQ}$ & $<L O Q$ & $<L O Q$ & $\mathrm{~N} / \mathrm{A}$ & $\mathrm{N} / \mathrm{A}$ & 0 \\
\hline
\end{tabular}




\begin{tabular}{|c|c|c|c|c|c|c|c|c|c|c|c|c|c|}
\hline \multicolumn{14}{|c|}{ THAU } \\
\hline \begin{tabular}{|l|} 
Parameter \\
Temperature
\end{tabular} & Juit & $27 / 04 / 2010 \mathrm{am}$ & $27 / 04 / 2010 \mathrm{pm}$ & $29 / 04 / 10$ & $03 / 05 / 10$ & $05 / 05 / 10$ & $07 / 05 / 10$ & $10 / 05 / 10$ & $13 / 05 / 10$ & $18 / 05 / 10$ & Average & Std Dev & $\mathrm{n}$ \\
\hline \multirow{2}{*}{$\begin{array}{l}\text { Temperature } \\
\text { Salinity }\end{array}$} & $\overline{\mathrm{I} C}$ & 18.7 & 19.6 & 20.4 & 19.4 & 16.1 & 15.7 & 17.1 & 17.5 & 16.2 & 17.9 & 1.7 & $\overline{9}$ \\
\hline & & 35.5 & 35.8 & 35.6 & 35.8 & 35.2 & 35.4 & 35.9 & 35.2 & 36.2 & 35.6 & 0.3 & 9 \\
\hline Dissolved Oxygen & $\mathrm{mg} / \mathrm{L}$ & 8.12 & 8.28 & 9.69 & 7.69 & 6.1 & 7 & 8.04 & 7.92 & 7.66 & 7.83 & 0.97 & 9 \\
\hline \begin{tabular}{|l} 
Dissolved Oxygen \\
\end{tabular} & $\%$ sat & 106.2 & 109.4 & 130 & 102.9 & 76.9 & 87.6 & 103.3 & 102 & 94.7 & 101.4 & 14.8 & 9 \\
\hline Daily average flow velocity & $\mathrm{cm} / \mathrm{s}$ & 1.25 & 1.25 & 1.8 & 1.29 & 2.47 & 1.31 & 2.02 & 1.5 & 1.45 & 1.59 & 0.42 & 9 \\
\hline Total suspended matter (TSS) & $\mathrm{mg} / \mathrm{L}$ & & 0.4 & 0.67 & 1.05 & & 1.42 & 0.83 & 1.25 & 0.57 & 0.89 & 0.37 & 7 \\
\hline Organic carbon in TSS & $\%$ & & 17.5 & 16.4 & 38.8 & & 26.7 & 19.3 & 30.8 & 20.3 & 24.3 & 8.3 & 7 \\
\hline NO2 & $\mu \mathrm{mol} / \mathrm{L}$ & & 0.02 & 0.03 & 0.04 & & 0.08 & 0.01 & 0.01 & 0.03 & 0.03 & 0.02 & 7 \\
\hline NO3 & $\mu \mathrm{mol} / \mathrm{L}$ & & 0.16 & 0.16 & 0.05 & & 0.16 & 0.06 & 0.05 & 0.1 & 0.11 & 0.05 & 7 \\
\hline $\mathrm{PO} 4$ & $\mu \mathrm{mol} / \mathrm{L}$ & & 0.09 & 0.11 & 0.09 & & 0.08 & 0.05 & 0.09 & 0.1 & 0.09 & 0.02 & 7 \\
\hline $\mathrm{NH} 4$ & $\mu \mathrm{mol} / \mathrm{L}$ & & 0.07 & 0.21 & 0.62 & & 0.34 & 0 & 0.04 & 0.18 & 0.21 & 0.22 & 7 \\
\hline Si & $\mu \mathrm{mol} / \mathrm{L}$ & & 4.11 & 4.49 & 9.17 & & 6.37 & 5.16 & 2.56 & 3.22 & 5.01 & 2.22 & 7 \\
\hline NO2 & $\mathrm{mg} / \mathrm{L}$ & & 0.43 & 0.65 & 0.87 & & 1.74 & 0.22 & 0.22 & 0.65 & 0.68 & 0.52 & 7 \\
\hline NO3 & $\mathrm{mg} / \mathrm{L}$ & & 2.58 & 2.58 & 0.81 & & 2.58 & 0.97 & 0.81 & 1.61 & 1.71 & 0.86 & 7 \\
\hline $\mathrm{PO} 4$ & $\mathrm{mg} / \mathrm{L}$ & & 0.95 & 1.16 & 0.95 & & 0.84 & 0.53 & 0.95 & 1.05 & 0.92 & 0.2 & 7 \\
\hline $\mathrm{NH} 4$ & $\mathrm{mg} / \mathrm{L}$ & & 3.89 & 11.67 & 34.44 & & 18.89 & 0.00 & 2.22 & 10.00 & 11.59 & 11.97 & 7 \\
\hline $\mathrm{Si}(\mathrm{OH}) 4$ & $\mathrm{mg} / \mathrm{L}$ & & 44.67 & 48.8 & 99.67 & & 69.24 & 56.09 & 27.83 & 35.00 & 54.47 & 24.09 & 7 \\
\hline TOC & $\mathrm{mg} / \mathrm{L}$ & & 1.9 & 1.7 & 1.8 & & 1.6 & 1.6 & 2.1 & 1.6 & 1.8 & 0.2 & 7 \\
\hline $\mathrm{DOC}$ & $\mathrm{mg} / \mathrm{L}$ & & 1.7 & 1.7 & 1.7 & & 1.4 & 1.5 & 1.7 & 1.4 & 1.6 & 0.1 & 7 \\
\hline $\mathrm{Ca}$ & $\mathrm{mg} / \mathrm{L}$ & & 430 & 450 & 430 & & 415 & 435 & 435 & 430 & 432 & 10 & 7 \\
\hline $\mathrm{Mg}$ & $\mathrm{mg} / \mathrm{L}$ & & 1340 & 1425 & 1345 & & 1315 & 1365 & 1325 & 1330 & 1349 & 37 & 7 \\
\hline Chlorophylle a & $\mu \mathrm{g} / \mathrm{L}$ & & 0.91 & 1.00 & 1.8 & & 2.69 & 1.21 & 1.59 & 0.92 & 1.45 & 0.65 & 7 \\
\hline \begin{tabular}{l|l} 
& Acetochlor \\
\cline { 2 - 2 }
\end{tabular} & $\begin{array}{ll}\mathrm{ng} / \mathrm{L} \\
\end{array}$ & & $\angle \mathrm{LLQ}$ & $\angle \mathrm{LQQ}$ & $\angle \mathrm{LQQ}$ & & $\angle \mathrm{LQQ}$ & $\angle \mathrm{LLQ}$ & & & & & 0 \\
\hline$\subsetneq$ Alachlor & $\mathrm{ng} / \mathrm{L}$ & & $<\mathrm{LQ}$ & $<\mathrm{LQ}$ & $<\mathrm{LQ}$ & & $<\mathrm{LQ}$ & $<\mathrm{LQ}$ & & & & & 0 \\
\hline Metolachlor & $\mathrm{ng} / \mathrm{L}$ & & 1.94 & 2.38 & 1.39 & & 2.48 & 0.44 & & & 1.73 & 0.84 & 5 \\
\hline$\stackrel{\varpi}{=}$ Deisopropylatrazine & $\mathrm{ng} / \mathrm{L}$ & & $<\mathrm{LQ}$ & $<\mathrm{LQ}$ & $<\mathrm{LQ}$ & & $<\mathrm{LQ}$ & $<\mathrm{LQ}$ & & & & & 0 \\
\hline o Desethylatrazine & $\mathrm{ng} / \mathrm{L}$ & & $<\mathrm{LQ}$ & 0.09 & $<\mathrm{LQ}$ & & $<\mathrm{LQ}$ & $<\mathrm{LQ}$ & & & 0.09 & & 1 \\
\hline Simazine & $\mathrm{ng} / \mathrm{L}$ & & 0.60 & 0.61 & 0.77 & & 0.56 & 1.13 & & & 0.73 & 0.24 & 5 \\
\hline $\begin{array}{l}\text { Atrazine } \\
\text { A }\end{array}$ & $\mathrm{ng} / \mathrm{L}$ & & 0.37 & 0.49 & 0.36 & & 0.25 & $\angle L Q$ & & & 0.37 & 0.10 & 4 \\
\hline Isoproturon & $\mathrm{ng} / \mathrm{L}$ & & 0.04 & 0.03 & 0.06 & & 0.07 & 0.04 & & & 0.05 & 0.02 & 5 \\
\hline Diuron & $\mathrm{ng} / \mathrm{L}$ & & 2.24 & 1.93 & 2.47 & & 2.63 & 2.79 & & & 2.41 & 0.34 & 5 \\
\hline \begin{tabular}{l|l} 
& Naphthalene \\
\cline { 2 - 3 }
\end{tabular} & $\overline{\mathrm{Ing} / \mathrm{L}}$ & & 2.2 & 1.9 & 0.9 & & 0.9 & 0.9 & 1.3 & 0.8 & 1.3 & 0.6 & 7 \\
\hline Acenaphthylene & $\overline{n g} / \mathrm{L}$ & & 0.2 & $<0.1$ & 0.8 & & 0.2 & 0.3 & 0.4 & $<0.1$ & 0.4 & 0.2 & 7 \\
\hline Acenaphthene & $\mathrm{ng} / \mathrm{L}$ & & $<0.1$ & 0.1 & $<0.1$ & & 0.1 & $<0.1$ & $<0.1$ & $<0.1$ & 0.1 & 0.0 & 7 \\
\hline \begin{tabular}{|l|} 
Fluorene \\
\end{tabular} & $n g / L$ & & 0.2 & 0.2 & 0.1 & & 0.2 & 0.2 & 0.3 & 0.2 & 0.2 & 0.1 & 7 \\
\hline Phenanthrene & ng/L & & 0.7 & 0.8 & 0.7 & & 0.6 & 0.6 & 0.9 & 0.5 & 0.7 & 0.1 & 7 \\
\hline Antracene & $\mathrm{ng} / \mathrm{L}$ & & $<0.1$ & $<0.1$ & $<0.1$ & & $<0.1$ & $<0.1$ & $<0.1$ & $<0.1$ & & & 7 \\
\hline ¿ Fluoranthene & ng/L & & 0.3 & 0.4 & 0.2 & & 0.4 & 0.5 & 0.5 & 0.2 & 0.3 & 0.1 & 7 \\
\hline Pyrene & $n g / L$ & & 0.1 & 0.3 & 0.2 & & 0.3 & 0.2 & 0.3 & 0.1 & 0.2 & 0.1 & 7 \\
\hline 胥 Benz(a)anthracene & $\mathrm{ng} / \mathrm{L}$ & & 0.1 & 0.1 & $<0.1$ & & 0.1 & $<0.1$ & $<0.1$ & $<0.1$ & 0.1 & 0.0 & 7 \\
\hline Co Chrysene & $\mathrm{ng} / \mathrm{L}$ & & 0.2 & 0.2 & 0.2 & & 0.2 & 0.2 & 0.1 & 0.1 & 0.2 & 0.0 & 7 \\
\hline$\geq$ Benzo(e)pyrene & $n g / L$ & & $<0.1$ & $<0.1$ & $<0.1$ & & $<0.1$ & $<0.1$ & $<0.1$ & $<0.1$ & & & 7 \\
\hline Wh Benzo(a)pyrene & $\mathrm{ng} / \mathrm{L}$ & & $<0.1$ & $<0.1$ & $<0.1$ & & $<0.1$ & $<0.1$ & $<0.1$ & $<0.1$ & & & 7 \\
\hline $\begin{array}{l}\text { Benzo(b)fluoranthene } \\
\text { + Benzo(j)fluoranthene } \\
\text { + Benzo(k)fluoranthene }\end{array}$ & ng/L & & $<0.1$ & 0.1 & 0.1 & & $<0.1$ & 0.1 & $<0.1$ & $<0.1$ & 0.1 & 0.0 & 7 \\
\hline Indeno(1,2,3-cd)pyrene & $\mathrm{ng} / \mathrm{L}$ & & $<0.1$ & $<0.1$ & $<0.1$ & & $<0.1$ & $<0.1$ & $<0.1$ & $<0.1$ & & & 7 \\
\hline Benzo(g,h,i)perylene & $n g / L$ & & $<0.1$ & $<0.1$ & $<0.1$ & & $<0.1$ & $<0.1$ & $<0.1$ & $<0.1$ & & & 7 \\
\hline Dibenz(a,h)anthracene & $n g / L$ & & $<0.1$ & $<0.1$ & $<0.1$ & & $<0.1$ & $<0.1$ & $<0.1$ & $<0.1$ & & & 7 \\
\hline Sum & Ing/L & & 4.0 & 4.1 & 3.1 & & 2.9 & 2.9 & 3.7 & 1.8 & & & \\
\hline Cobalt & Ing/L & & 81.1 & 75.7 & & 43.9 & & & & & 66.9 & 20.1 & 3 \\
\hline Nickel & $\mathrm{ng} / \mathrm{L}$ & & 340.7 & 626.5 & & 395.1 & & & & & 454.1 & 151.7 & 3 \\
\hline Copper & ng/L & & 830.5 & 1013.0 & & 663.3 & & & & & 835.6 & 174.9 & 3 \\
\hline Zinc & $\mathrm{ng} / \mathrm{L}$ & & 0.7 & 0.6 & & 0.7 & & & & & 0.7 & 0.1 & 3 \\
\hline Cadmium & $\mathrm{ng} / \mathrm{L}$ & & 15.8 & 16.8 & & 10.8 & & & & & 14.5 & 3.2 & 3 \\
\hline Lead & ng/L & & 21.2 & 20.6 & & 16.5 & & & & & 19.4 & 2.6 & 3 \\
\hline
\end{tabular}

N/A: not available 